\title{
Africa's Oil Abundance and External Competitiveness: Do Institutions Matter?
}

\author{
Mahvash Saeed Qureshi
}





\title{
IMF Working Paper
}

\author{
African Department
}

\section{Africa's Oil Abundance and External Competitiveness: Do Institutions Matter? ${ }^{1}$ \\ Prepared by Mahvash Saeed Qureshi}

Authorized for distribution by Cyrille Briançon

July 2008

\begin{abstract}
This paper examines the structural competitiveness of oil-rich economies in sub-Saharan Africa relative to other major oil-exporting developing countries, and investigates the reasons for systematic differences in the non-oil export performance across these economies. The analysis reveals that oil-rich Africa lags behind other oil-exporters in terms of diversification, global market share and the overall investment climate. The poor performance of their nonoil sector can be largely attributed to weak infrastructure and institutional quality. The results also show that institutional quality is a significant determinant of the extent to which oil abundance affects the competitiveness of the non-oil sector; thereby explaining the divergent experiences of oil-rich economies across the world. This implies that oil wealth does not necessarily weaken the non-oil tradable sector; countries may mitigate the impact of Dutch disease and benefit from oil booms if revenues are used prudently to reduce oil dependence.
\end{abstract}

\section{This Working Paper should not be reported as representing the views of the IMF.}

The views expressed in this Working Paper are those of the author and do not necessarily represent those of the IMF or IMF policy. Working Papers describe research in progress by the authors and are published to elicit comments and to further debate.

17BJEL Classification F12, F41, O13, Q32

Numbers:

Keywords: oil abundance, competitiveness, institutions, gravity model, sub-Saharan Africa Author's E-Mail Address: mqureshi@imf.org

\footnotetext{
${ }^{1}$ I am grateful to Cyrille Briançon, Arto Kovanen, Alexander Kyei, Jean Le Dem, Calvin McDonald, Bernardin Akitoby, Charalambos Tsangarides, Raju Singh, Chad Steinberg, Camelia Minoiu, and Izabela Karpowicz for helpful comments and suggestions. Any errors are my responsibility.
} 
I. Introduction 3

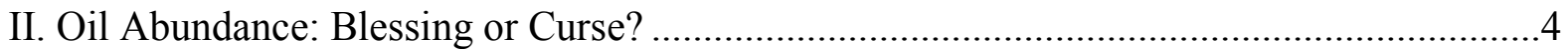

A. Africa's Oil Riches and Competitiveness ..............................................................

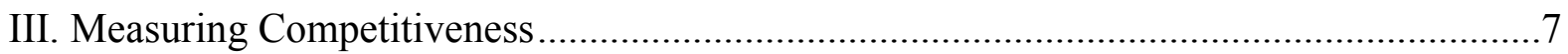

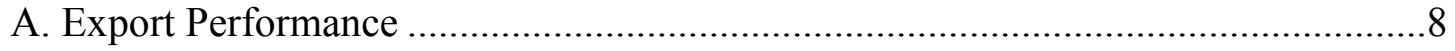

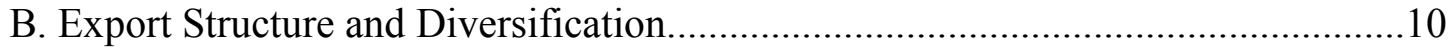

C. Productivity, Infrastructure, and Human Capital ....................................................15

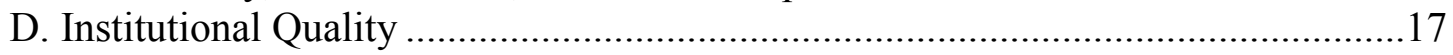

IV. Institutional Quality and Export Competitiveness...................................................21

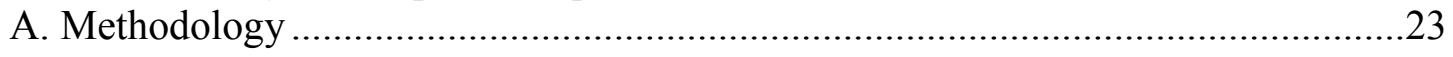

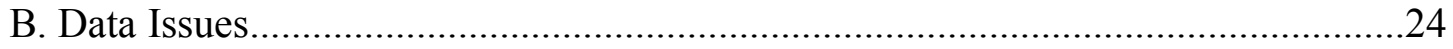

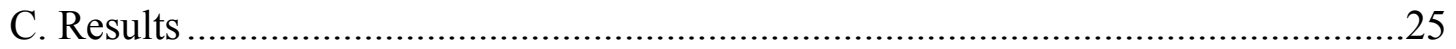

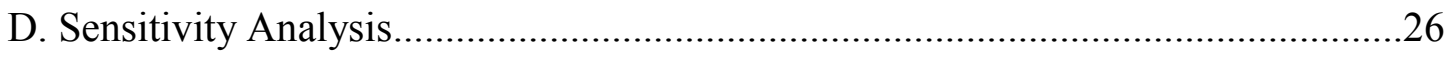

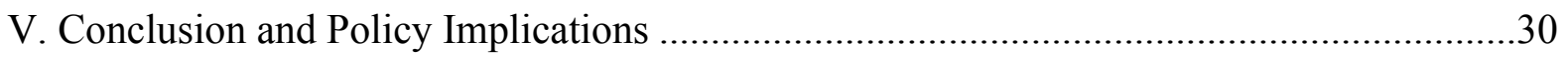

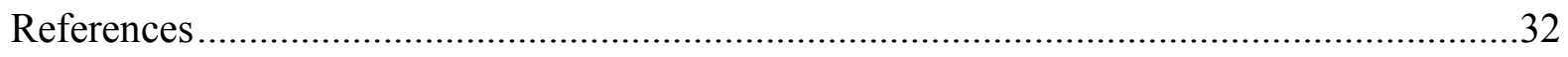

Tables

1. Export Structure by Product Category, 1970-2005 ….................................................10

2. Product Categories with Revealed Comparative Advantage, 1970-2005 .........................13

3. Sectoral Distribution of Revealed Comparative Advantage, 2005 .................................13

4. ICT and Transport Infrastructure Indicators for Selected Economies, 2005 ....................16

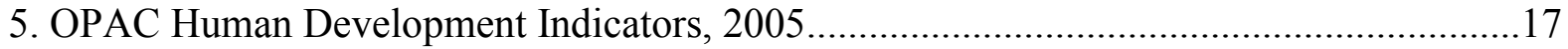

6. Institutions and Real Non-oil Exports: Estimates for the World Sample ..........................28

7. Institutions and Real Non-oil Exports: Estimates for Sub-Saharan Africa........................29

8. Estimates for Countries with Low and High Institutional Quality .................................30

Figures

1. Growth in Total and Oil Export Volume, 1970-2006 ….............................................8

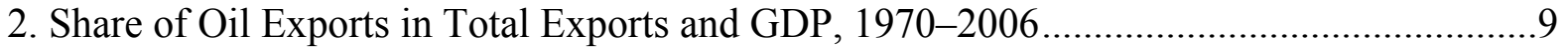

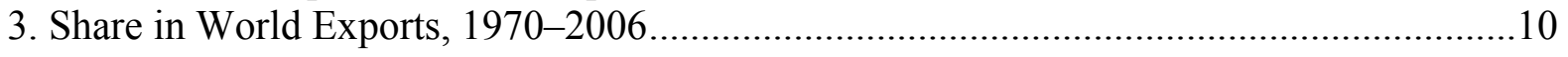

4. Export Structure and Concentration, 1970-2005 ...................................................... 14

5. World Share of Nonfuel Merchandise Exports, 1970-2005 .............................................15

6. Real GDP and Non-oil GDP per Capita (US\$ thousands), 1970-2006...........................15

7. DBI Ranking for OPAC and Selected Economies, 2007 ...........................................18

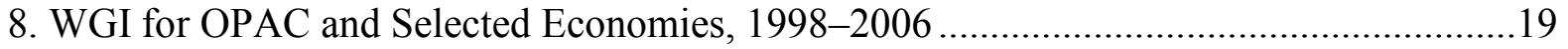

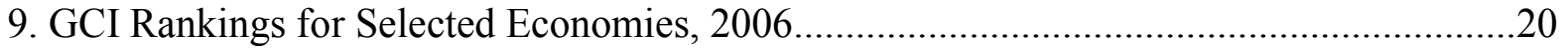

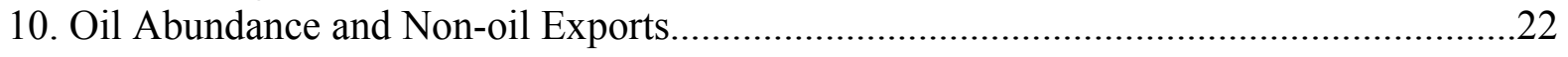

Appendixes

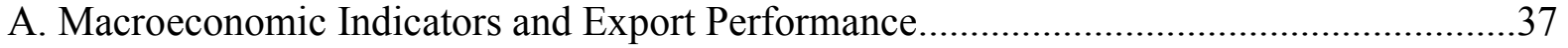

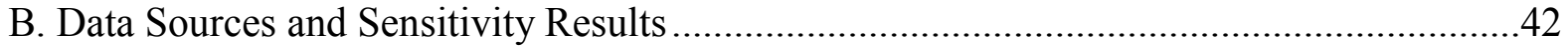




\section{INTRODUCTION}

In recent years, the sustained growth in global oil demand and the resultant steady increase in oil prices have allowed the oil-producing African countries (OPAC) to improve their export and growth performances. ${ }^{2}$ The OPAC had average annual GDP growth of over 7 percent in 2000-06 while Sub-Saharan Africa (SSA) grew at 4.7 percent and the global economy at 4.3 percent. However, one of the major threats to sustaining this impressive growth rate is the lack of competitiveness of the non-oil sector in these economies. Their heavy reliance on oil revenues makes them highly vulnerable to external shocks and leaves their long-run economic prospects uncertain.

The appreciation of exchange rates in the African oil exporters, especially after the first oil shock in the early 1970s, is often viewed as the main reason behind the contraction of their tradable sector. Recent studies, however, note that the performance of tradables, especially the manufacturing sector, did not improve even after consequent devaluations. ${ }^{3}$ Structural factors like ill-planned economic policies, low productivity, poor management of public finances and an overall weak investment climate may thus have operated to hinder OPAC's diversification and external competitiveness. The importance of these factors becomes even more evident when we observe that some other oil exporting countries, which experienced the same oil price shocks as the OPAC, built strong non-oil sectors over time and successfully reduced their reliance on oil revenues.

However, while the role of structural factors, especially institutional quality, has been well explored in the context of promoting economic growth in resource rich economies, to the best of our knowledge, no study explicitly investigates their importance in mitigating the impact of Dutch disease in resource abundant countries. ${ }^{4}$ In this paper, we extend the existing literature by focusing on this issue in the context of oil rich SSA economies. We examine the competitiveness of OPAC by building a historical backdrop to illustrate developments in their non-oil sector since 1970, and review a range of indicators to assess the quality of infrastructure, human capital, and institutions in these economies. OPAC's indicators are compared with those of other oil-exporting developing countries, namely, Indonesia, Mexico, Trinidad and Tobago, the United Arab Emirates (UAE), and Venezuela, to put in perspective the structural reasons for the lackluster performance of their non-oil sector. ${ }^{5}$ Further, based

\footnotetext{
${ }^{2} \mathrm{OPAC}$ is an unofficial acronym used here for convenience purposes. It refers to the leading oil exporters in Sub-Saharan Africa: Angola, Cameroon, Chad, Republic of Congo, Côte d'Ivoire, Equatorial Guinea, Gabon, and Nigeria.

${ }^{3}$ Nigeria's nominal exchange rate (against the U.S. dollar) was devalued by about 34 percent in 1986, while Cameroon, Chad, Congo, Côte d'Ivoire, Equatorial Guinea and Gabon, which are part of the CFA Franc zone, devalued by 49 percent in 1994. See Fukunishi (2004) for a discussion on the impact of devaluation on the manufacturing sector in SSA.

${ }^{4}$ Among others, Sachs and Warner (1995), Sala-i-Martin and Subramanian (2003), Mehlum, Moene and Torvik (2005), and Iimi (2007), investigate the importance of institutions for economic growth in natural resource abundant economies.

${ }^{5}$ The selected comparator countries comprise some of the major oil-exporting developing countries located in different regions across the world.
} 
on the findings of the comparative analysis, we employ the gravity model of bilateral trade flows to formally evaluate the significance of structural factors, especially institutional quality, in explaining the divergent experiences of oil-rich economies in general and of SSA in particular.

Our analysis reveals that most OPAC have a highly concentrated economic base.

Performance of their nonfuel merchandise sector has been dismal, and their share in world exports has declined steadily. However, this is not true for Indonesia, Mexico, and the UAE, which are also oil exporters but managed to diversify their exports over time. These countries have a relatively strong investment climate and appear to have benefited significantly from good infrastructure and institutions. This observation is confirmed from the estimates obtained from the gravity model of trade, which show that oil abundance negatively but infrastructure and institutions positively affect non-oil exports. More importantly, the results show that institutional quality is a significant determinant of the extent to which oil abundance affects the competitiveness of the non-oil sector. Thus, oil revenues do not necessarily weaken the tradable sector; in fact, countries may benefit substantially from booms if oil revenues are managed appropriately and used to create an environment that promotes the non-oil sector.

In what follows, Section II reviews the background to this research. Section III reviews the non-oil export performance of the OPAC and presents a detailed comparative analysis of structural indicators of competitiveness. Section IV explores the importance of structural factors, particularly, institutional quality, in explaining the divergent experiences of oil- rich economies across the world and in SSA. Section V concludes with policy implications.

\section{Oil Abundance: Blessing OR Curse?}

The relationship between natural resource abundance, particularly oil, and economic performance has been a subject of much theoretical and empirical research after a number of earlier studies, for example, Neary and Van Wijnbergen (1986) and Auty (1990), noted shortcomings in the economic performance of resource rich economies during the 1970s and 1980s. Using cross-country growth regressions, Sachs and Warner (1995), Leite and Weidman (1999), and Sala-i-Martin and Subramanian (2003) confirm that resource poor countries have outperformed resource rich economies in terms of economic growth.

The adverse effects of resource abundance on growth appear surprising since natural resources increase a country's wealth and in this respect alone are expected to increase investment and improve economic performance. Numerous explanations have been proposed for the observed failure of resource-led development, which are commonly grouped into two broad categories: political economy, and macroeconomic. ${ }^{6}$ The political economy explanation, also known as the resource curse thesis, focuses on governance issues: natural

\footnotetext{
${ }^{6}$ See Iimi (2007) for a detailed review of literature on the implications of resource abundance for economic growth.
} 
resource revenues create aggressive rent-seeking, corruption, and wasteful public expenditure, and increase the likelihood of conflict and political repression, thereby hampering growth.

The macroeconomic explanation makes Dutch disease the key reason for the poor performance of resource abundant countries. It argues that after the positive shock of a natural resource discovery, there is a resource movement effect (factors of production move to the booming natural resource sector, which causes a shift in production in that direction) and a spending effect (the additional revenue from the resource boom increases demand for nontraded goods such as labor, raising their price and causing an appreciation of the real exchange rate) that make the tradable sector, particularly manufacturing, less competitive and results in de-industrialization of the economy. ${ }^{7}$ Since technological growth tends to be lower in the non-tradable relative to the tradable sector, movement away from manufacturing implies lower technological and long-run economic growth rates (Van Wijnbergen, 1984). Further, as dependence on natural resources increases, growth may be dampened through another channel: economic volatility. Prices of natural resources are volatile in general and abrupt changes tend to impose heavy costs in terms of income, investment, and economic development.

However, despite the potentially adverse effects of resource abundance, some resource-rich countries have performed exceptionally well. For example, Norway, which is richly endowed with oil and minerals, industrialized successfully and has one of the highest per capita incomes in the world. Among the developing countries, Indonesia is a notable success story. It controlled the effects of the first oil shock and its non-oil tradable goods base expanded rapidly in the 1980s. The experience of these and several other countries suggests that resource curse and Dutch disease are not inevitable phenomena. For example, in a comparative analysis of Indonesia and Mexico, Usui (1997) finds that policy adjustments, macroeconomic management, and the strategic use of oil revenues are critical for averting Dutch disease. Similarly, Hilaire and Doucet (2004) argue that through a combination of human capital development and controlled spending, oil-rich countries can avoid falling into the Dutch disease trap and ensure gains from oil booms. However, while the negative association between resource abundance and economic growth has been well researched, there has been little investigation into the policy instruments and conditions of successful oil-rich countries to avoid Dutch disease (Mainardi, 1995).

\section{A. Africa's Oil Riches and Competitiveness}

Africa has some of the leading oil-exporting nations in the world. Together, its eight major oil-exporting countries-Angola, Cameroon, Chad, the Republic of Congo, Côte d'Ivoire, Equatorial Guinea, Gabon, and Nigeria - contributed 7.5 percent of world exports in

\footnotetext{
${ }^{7}$ De-industrialization may be a long-run phenomenon: as production shifts toward the booming nontradable sector, overall technological growth slackens and the country loses its comparative advantage in the tradable sector. Thus, firms are reluctant to invest in the manufacturing sector even if the natural resource is exhausted or its price falls, making it difficult for the economy to rebuild its manufacturing base (Krugman, 1987).
} 
2003-06. Angola, Nigeria, and Gabon have been exporting oil since the 1960s; others, like Chad, Côte d'Ivoire, and Equatorial Guinea, began exporting oil relatively recently.

However, despite the oil wealth of these economies, none of them has emerged as an important player in the global economy. Their non-oil GDP growth has lagged behind that of non-oil intensive African countries throughout the last decade. ${ }^{8}$ For most of OPAC, the contribution of the tradable sector, especially manufacturing, is not only small, it has been declining steadily. This is in contrast to the experience of some other oil-producing developing countries, notably Indonesia and the UAE. ${ }^{9}$

Since the manufacturing sector plays a critical role in spurring technological innovation, generating employment, building human capital, and enhancing productivity, the OPAC appear to have lost their competitiveness in international markets. Although a number of studies have assessed the competitiveness of SSA as a region, such research is limited for the OPAC. ${ }^{10}$ For SSA, the diversification process has been slow, volatile, and negatively influenced by the discovery of primary resources that induced movement away from other sectors. Stagnant growth in manufacturing and SSA's falling share in global trade has been attributed to economic instability, high and cascading tariff structures, poor business environment, weak governance and institutions, small domestic markets, high indirect costs, low productivity, and poor economic and trade policies (Collier, 1997; Gupta and Yang, 2006; UNECA, 2007).

SSA has also been characterized by technical inefficiency and lower productivity than other developing countries (Pack, 1987; Tybout, 2000). Biggs, Shah, and Srivastava (1995) argue that the manufacturing sector in Africa stagnated because of a lack of "technological capability," defined as the information and skills needed to effectively utilize technology, rather than technological backwardness. Comparisons of wages and unit labor costs between SSA and other low-income countries observe that wages in SSA vary more and on average tend to be higher, particularly in the CFA franc zone (Biggs and Srivastava, 1996; Bigsten et al., 2000).

Exchange rate assessments show that currencies in SSA were overvalued from the 1960s to the 1980s (Ghura and Grennes, 1993; Collier and Gunning, 1999). Söderling (2000) and Sekkat and Varoudakis (2000) estimate that the overvalued exchange rate hurt manufacturing exports by 30-100 percent. However, in the context of OPAC, an interesting point is that all the economies experienced exchange rate devaluation at some point after the first oil shock. Nigeria's nominal exchange rate was devalued in 1986 by 34 percent, Angola undertook stepped devaluation in the early 1990s that resulted in an average annual nominal exchange rate devaluation of about 88 percent during 1991-97, and the six countries in the CFA franc

\footnotetext{
${ }^{8}$ See Table A1 in Appendix A.

${ }^{9}$ See Table A2 in Appendix A.

${ }^{10}$ Sachs and Warner (1995), Sala-i-Martin and Subramanian (2003), and IMF (2007), analyze the growth pattern of oil-rich African countries and propose ways to ensure that oil revenues are spent efficiently.
} 
zone devalued their currency in early 1994. However, the devaluation does not appear to have had a long term impact on the performance of the non-oil tradable sector in any of the economies and their exports continue to be dominated by oil. This is because, as mentioned above, currency devaluations may not reverse the adverse impacts of an oil boom in the absence of appropriate macroeconomic conditions and policies. ${ }^{11}$

\section{Measuring Competitiveness}

The traditional analysis of competitiveness focused mainly on real exchange rate (RER) assessments. The RER may be assessed using price-based competitiveness indicators such as relative purchasing power parity (PPP) exchange rates, the Consumer Price Index (CPI)based RER, and internal terms of trade, or through more formal econometric analyses involving estimation of a reduced-form relationship between the equilibrium exchange rate and its fundamental determinants using single-country or panel datasets. ${ }^{12}$ However, RER assessments for developing economies are often unreliable due to the poor quality and availability of data, frequent structural breaks, economic volatility, and market imperfections (Di Bella, Lewis, and Martin, 2007). For example, Chudik and Mongardini (2007) estimate the equilibrium exchange rate in the OPAC and find limited robustness of results, which they attribute to the relatively small cross-country and time dimensions of their dataset.

In recent years, the importance of nonprice determinants of competitiveness has been emphasized to get a holistic view of competitiveness and derive policy guidance. These determinants are even more important for economies where exchange rate movements alone have not delivered the expected results. For example, the World Economic Forum (WEF, 2007) argues that competitiveness should be viewed from a broad perspective as "the set of institutions, policies, and factors that drive productivity and therefore set the sustainable current and medium-term levels of economic prosperity."

A number of recent studies have therefore adopted a multidimensional approach to examine competitiveness, and analyze structural issues in addition to exchange rate assessments (see, for example, Murgasova, 2004; Di Bella, Lewis and Martin, 2007; Ramirez and Tsangarides, 2007). Following these studies, we assess OPAC's structural competitiveness by examining a range of indicators and group them into four broad categories: (i) export performance, (ii) export structure and diversification, (iii) productivity, infrastructure, and human capital, and (iv) institutional quality.

\footnotetext{
${ }^{11}$ For example, Collier (1994) argues that the weak response of exports to devaluation in Nigeria reflects a reluctance to commit investment to the non-oil export sector that may have been the result of low government credibility and its inability to pre-commit to the maintenance of policies.

${ }^{12}$ Cerra and Saxena (2002) and Abdih and Tsangarides (2008) are examples of single-country equilibrium RER estimations. Panel estimations include Dufrenot and Yehoue (2005) and Chudik and Mongardini (2007).
} 


\section{A. Export Performance}

The massive wave of international trade liberalization over the past decade has increased OPAC's participation in global trade. OPAC's total trade (exports and imports) as a share of GDP increased from 70 percent to 88 percent between 1970 and 1999 and to 103 percent in 2000-06. In contrast, the trade-to-GDP ratio for the entire SSA region increased from about 55 percent in 1970-99 to 66 percent in 2000-06, while that for the world increased from 38 percent to 50 percent.

The expansion in OPAC trade activity has been driven mainly by an increase in exports. The real exports of OPAC goods and services increased at an average annual rate of 6.9 percent between 1970 and 2006 (see Figure 1). ${ }^{13}$ Meanwhile, the real exports of SSA grew annually at 3.8 percent and of the entire global economy at 6.5 percent. OPAC appear to have done well in terms of export growth even compared with other oil-exporting countries such as Indonesia, Mexico, Trinidad and Tobago, Venezuela, and the UAE. This is especially true in recent years when annual export growth in OPAC outperformed other economies and grew at nearly double the pace of the world economy.

Figure 1. Growth in Total and Oil Export Volume, 1970-2006

(Percent)

(a) Growth in Total Export Volume, 1970-2006 (percent)

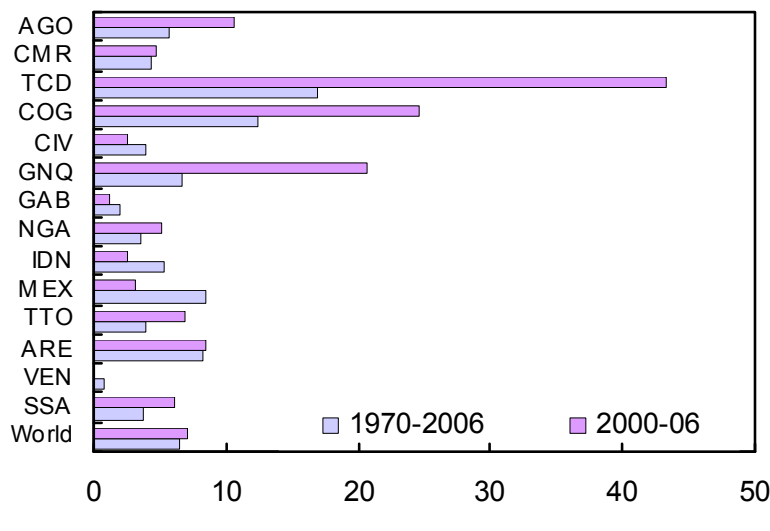

Source: World Economic Outlook database. (b) Growth in Oil Export Volume, 1970-2006 (percent)

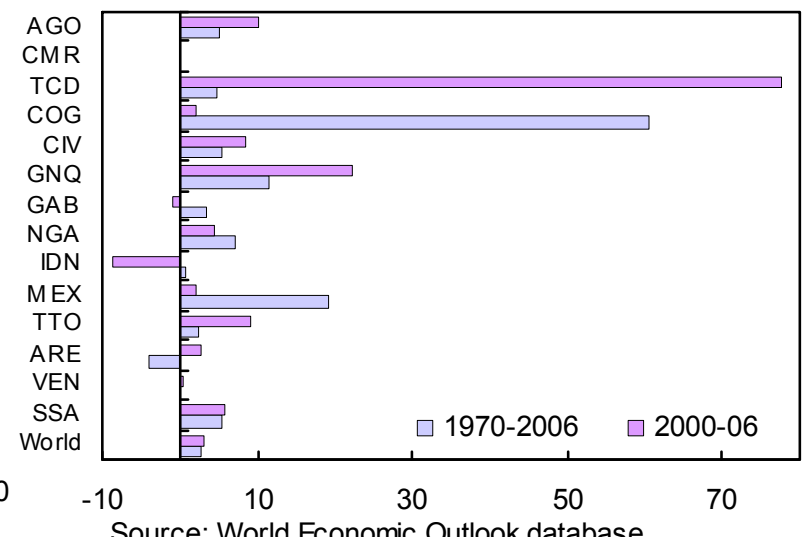

Source: World Economic Outlook database.

13 The following international standard country codes are used in the figures hereafter: Angola=AGO; Cameroon=CMR; Chad=TCD; Congo (Rep. of) $=\mathrm{COG}$; Côte d'Ivoire=CIV; Equatorial Guinea=GNQ; Gabon $=\mathrm{GAB}$; Indonesia $=\mathrm{IDN}$, Mexico $=\mathrm{MEX}$; Nigeria $=\mathrm{NGA}$; Trinidad and Tobago $=\mathrm{TTO}$; United Arab Emirates $=\mathrm{ARE}$; and Venezuela $=\mathrm{VEN}$. 
However, a closer look at the pattern of export growth in OPAC reveals that it is mainly driven by oil exports. Oil constitutes over 70 percent of the total exports of Angola, Chad, Congo, Equatorial Guinea, Gabon and Nigeria, and 30-40 percent for Cameroon and Côte d'Ivoire (Figure 2). The contribution of oil exports to GDP is also substantial in these economies, averaging about 50 percent in 2000-06. These ratios are much higher than those of Indonesia, Mexico, and the UAE but similar to those of Trinidad and Tobago and Venezuela. ${ }^{14}$

In an international context, OPAC's trade performance has been far from satisfactory. Its share of world goods exports dropped from 1.5 percent in 1970-80 to 0.7 percent in 1990-2006, and its share of world exports of services remains negligible (Figure 3). The poor performance of OPAC in world trade becomes even more evident when oil and non-oil exports are examined separately: while OPAC's share of world oil exports has stayed fairly constant since the mid-1980s, its share of world non-oil exports dropped from 0.6 percent in 1970 to a meager 0.2 percent in $2006 .^{15}$

Figure 2. Share of Oil Exports in Total Exports and GDP, 1970-2006

(Percent)

(a) Share of Oil Exports in Total Exports

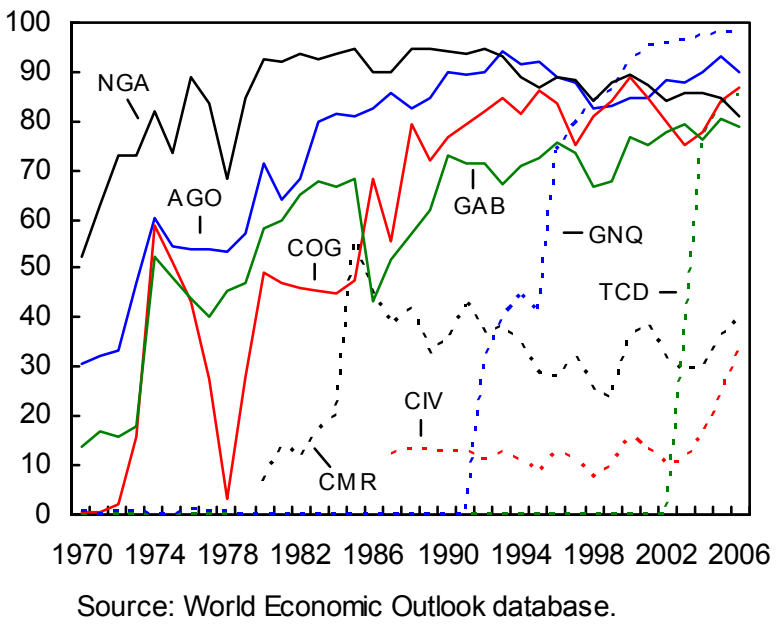

(b) Share of Oil Exports in GDP

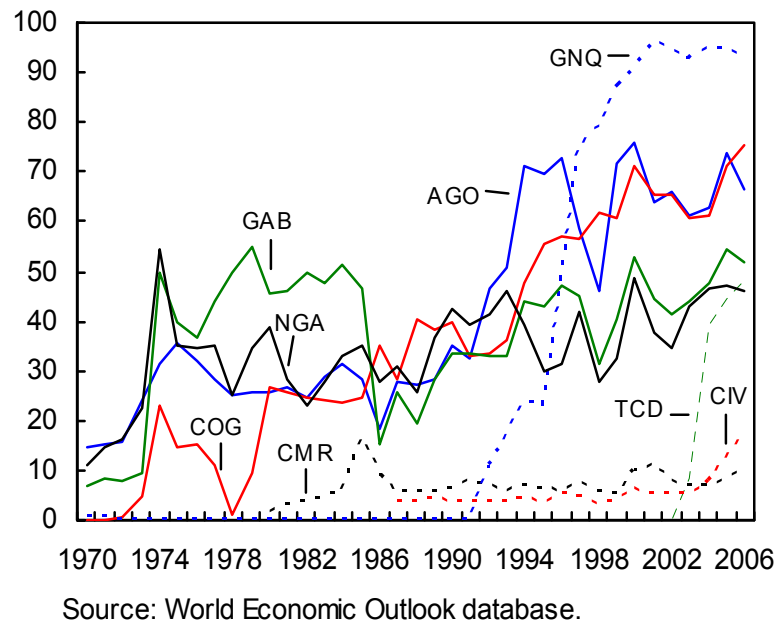

\footnotetext{
${ }^{14}$ The share of oil exports in total exports (GDP) was about 10 (4) percent for Indonesia, 11 (3) percent for Mexico, 58 (35) percent for Trinidad and Tobago, 45 (37) percent for the UAE, and 81 (27) percent for Venezuela in 2000-06.

${ }^{15}$ In terms of individual countries, the share of non-oil exports in world exports of goods and services declined for all eight African oil exporters between 1970-89 and 2000-06, unlike Indonesia, Mexico, the UAE, and Venezuela (Table A3). Interestingly, Trinidad and Tobago, which has a much smaller domestic market than the OPAC, also managed to maintain its share of non-oil exports in the world market.
} 
Figure 3. Share in World Exports, 1970-2006

(Percent)

(a) Share in World Exports of Goods and Services ${ }^{1 /}$

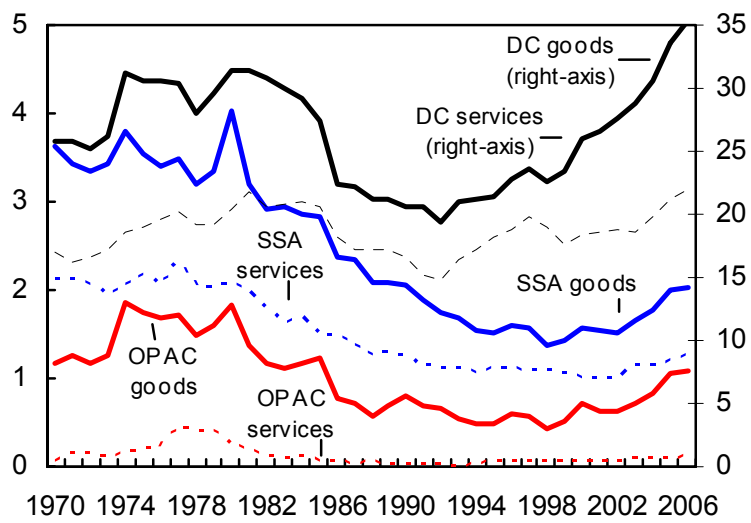

Source: World Economic Outlook database. 1/ DC=Developing countries; SSA=Sub-Saharan Africa; OPAC=Oil-producing African countries. ((b) Share in World Oil and Non-oil Exports

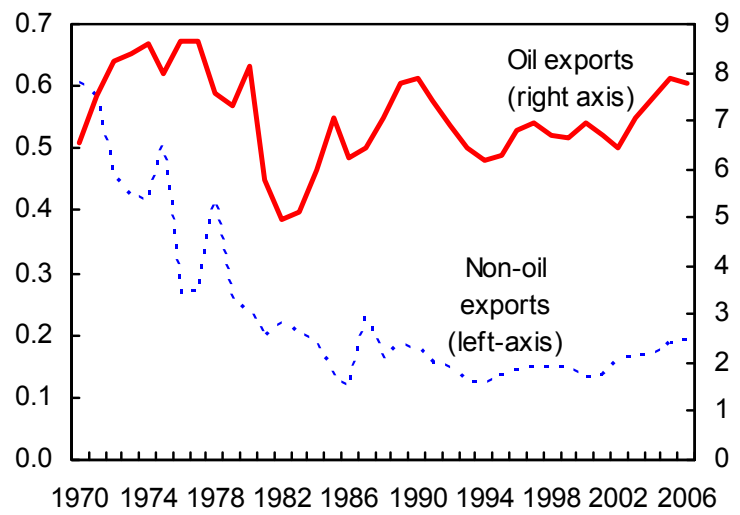

Source: World Economic Outlook database.

\section{B. Export Structure and Diversification}

In the last two decades, developing countries together experienced a remarkable shift in their export structures. Exports of primary commodities accounted for about 75 percent of their total exports in the early 1980s, but about 70 percent of their total exports are manufactures today (UNCTAD, 2003). The export structure of the OPAC, however, exhibits a different trend.

Primary commodities, especially fuel-based primary commodities, continue to be their most important export (see Table 1). ${ }^{16}$ The share of manufacture exports in total merchandise exports has either held fairly constant since the 1970s or fallen. For Côte d'Ivoire and Congo, the share of manufacture exports increased between 1970 and 1999 but dropped in 2000-05 as petroleum exports surged upwards due to the global rise in oil demand.

Table 1. Export Structure by Product Category, 1970-2005 (Percent) ${ }^{1}$

\begin{tabular}{lccccccccc}
\hline & \multicolumn{3}{c}{ Primary Commodities $^{2}$} & \multicolumn{2}{c}{ Nonfuel Primary Commodities } & \multicolumn{3}{c}{ Manufactures } \\
\hline & $1970-89$ & $1990-99$ & $2000-05$ & $1970-89$ & $1990-99$ & $2000-05$ & $1970-89$ & $1990-99$ & $2000-05$ \\
\hline AGO & 94 & 94 & 94 & 25 & 01 & 01 & 05 & 06 & 06 \\
CMR & 92 & 91 & 92 & 65 & 52 & 47 & 03 & 04 & 04 \\
COG & 87 & 75 & 95 & 28 & 12 & 11 & 10 & 24 & 03 \\
CIV & 95 & 89 & 92 & 91 & 82 & 79 & 05 & 11 & 08 \\
GNQ & 95 & 94 & 96 & 95 & 63 & 05 & 04 & 05 & 04 \\
GAB & 94 & 97 & 96 & 28 & 23 & 20 & 05 & 03 & 03 \\
NGA & 99 & 98 & 98 & 07 & 04 & 03 & 01 & 02 & 01 \\
IDN & 91 & 52 & 44 & 29 & 22 & 21 & 07 & 47 & 53 \\
MEX & 53 & 22 & 17 & 26 & 10 & 06 & 40 & 73 & 79 \\
TTO & 87 & 60 & 66 & 06 & 13 & 05 & 12 & 39 & 33 \\
UAE & 93 & 82 & 72 & 02 & 04 & 05 & 4 & 15 & 25 \\
VEN & 94 & 81 & 84 & 05 & 06 & 04 & 03 & 14 & 13 \\
\hline
\end{tabular}

Source: UN-COMTRADE database.

${ }_{1}^{1}$ Angola=AGO; Cameroon=CMR; Chad=TCD; Congo (Rep. of)=COG; Côte d'lvoire=CIV; Equatorial Guinea=GNQ; Gabon=GAB; Indonesia=IDN, Mexico=MEX; Nigeria=NGA; Trinidad and Tobago=TTO; United Arab Emirates=ARE; and Venezuela=VEN;

${ }^{2}$ Primary commodities are defined as SITC sections 0 to 4; nonfuel primary commodities as SITC sections $0,1,2$ and 4; manufactures as SITC sections 5,6 (less 68 ), 7, and 8.

${ }^{16}$ Chad is not included in this analysis because of lack of relevant data. 
Disaggregated export data shows that OPAC's export structure is highly concentrated. ${ }^{17}$ The combined exports of the top five merchandise export sectors (including fuels) constitute over 90 percent of total exports in Angola, Congo, Equatorial Guinea, Gabon, and Nigeria, and about 80 percent in Côte d'Ivoire and Cameroon. Besides petroleum, other important sectors for these economies are wood and wood products, cocoa, gems, fresh fruits and nuts, and ores and concentrates of nonferrous base metals. However, the export structure of most other oil producers appears to have changed over time. For example, whereas the share of the leading five export sectors in merchandise exports was 71 percent in 1970 in Indonesia, it dropped to 33 percent in 2005. Similarly, in the UAE, this share fell from 96 percent in 1970 to 75 percent in 2005 .

To get a detailed insight into the key trends and developments in OPAC's export structure, we compute the traditional Pearson's correlation coefficient $(r)$, which measures the linear association of two variables, between sectoral export shares in the initial year (1970) and those in other years. Values of $r$ closer to one indicates similarity in the composition of exports with the initial year, and $r$ closer to zero indicates dissimilarity. Tajoli and De Benedictis (2006) argue that $r$ is influenced by extreme values and is an inappropriate measure for skewed distributions. Hence, we also measure similarity $(S)$ in terms of 'distance' using the Bray-Curtis $(B C)$ measure, as follows:

$$
S=1-B C=1-\frac{\sum_{j=1}^{n}\left|x_{j(t+k)}-x_{j t}\right|}{\sum_{j=1}^{n}\left(x_{j(t+k)}+x_{j t}\right)},
$$

where $x_{\mathrm{j}}$ is the sectoral share of sector $j$ in total merchandise exports, $t$ is the initial year, and $k$ represents the following years. $B C$ is a bounded measure $(0 \leq B C \leq 1)$ that is suitable for asymmetric distributions and is less sensitive to the subclassification of sectors.

In addition, we explore the evolution and dynamics of export diversification by computing the exports concentration $(E C I)$ and revealed comparative advantage $(R C A)$ indices. The $E C I$ is defined as:

$E C I_{i}=\frac{\sqrt{\sum_{j=1}^{n}\left(x_{j}\right)^{2}-1 / n}}{1-\sqrt{1 / n}}$.

where $x_{\mathrm{j}}$ is the sectoral share of sector $j$ in total merchandise exports and $n$ is the total number of product categories. The $E C I$ ranges from zero to one where values closer to zero indicate lower concentration and a highly diversified export pattern, and those closer to one indicate higher concentration and little diversification.

\footnotetext{
${ }^{17}$ See Table A4 in Appendix A.
} 
The $R C A$, which is an indicator of a country's relative export performance in particular commodities, is computed as:

$R C A_{i j}=\frac{\left(x_{i j} / x_{w j}\right)}{\left(X_{i} / X_{w}\right)}$,

where $x_{\mathrm{ij}}$ and $x_{\mathrm{wj}}$ denote exports of product $j$ from country $i$ and the world, respectively; $X_{\mathrm{i}}$ refers to total exports of country $i$; and $X_{\mathrm{w}}$ to total world exports. The $R C A$ measures the share of a given product in a country's total exports relative to the product's share in total world exports. A value equal to or greater than one indicates that the country is a relatively efficient producer in that sector and specializes in its production, while a value of less than one indicates that the country is a relatively inefficient producer in the given sector.

The measures - $r, S, E C I$ and $R C A$ - are computed using export data at the three-digit Standard Industrial Trade Classification (SITC) (Revision 1) level comprising 182 product categories. ${ }^{18}$ The plots presented in Figure 4 reveal some interesting trends. First, we note that the ECI has risen for all OPAC, but the increase is much more pronounced for Angola, Congo, Equatorial Guinea, Gabon, and Nigeria. The value of ECI for Angola, Equatorial Guinea, and Nigeria is close to 1 and for Congo and Gabon about 0.8, indicating a highly concentrated export structure. Equatorial Guinea only started exporting oil in the second half of the 1990s, and its ECI has risen sharply since then. Cameroon and Côte d'Ivoire have a relatively lower and fairly stable $E C I$, which averaged about 0.5 for $1970-2005$, and indicates a moderately diversified export base.

Second, it is apparent that the economies of Angola, Nigeria, Gabon, and to some extent Congo were not able to build a strong manufacturing base after the first oil shock in the early 1970s. However, this does not appear to be true for other oil-exporting developing countries where concentration has been declining since then. Overall, the export structure of Indonesia and Mexico is highly diversified and that of Trinidad and Tobago and the UAE moderately diversified. Venezuela's export concentration decreased steadily until 2000 but has been increasing recently as its oil exports have surged.

Third, the similarity measures, $r$ and $S$, indicate a pattern fairly similar to the $E C I$ : the composition of exports changed significantly in the OPAC - inclining heavily toward oilonce a country started exporting oil but stabilizes after that. This is in contrast especially to Indonesia, Mexico, and the UAE, which experienced a constantly changing export composition as they moved gradually toward relatively dynamic products, such as clothing, machinery, and consumer electronics.

\footnotetext{
18 Thanks are due to Nadeem Akhtar for assistance in compiling data for the computations.
} 
In terms of the revealed comparative advantage, Table 2 shows the number of product categories in which the OPAC had an $R C A$ equal to or greater than one. Of the seven, Côte d'Ivoire is the only country that has developed a specialization in new product categories; products in which it reveals a comparative advantage increased from 16 in 1970-79 to 25 in 2000-05. Angola is at the other extreme: the number of product categories that it produced relatively efficiently has dropped from 15 in the 1970 s to 3 . Meanwhile, all the comparator developing countries except Mexico increased the number of product categories in which they had a comparative advantage.

Table 2. Product Categories with Revealed Comparative Advantage, 1970-2005 ${ }^{1}$

\begin{tabular}{lcccc}
\hline & $\mathbf{1 9 7 0 - 7 9}$ & $\mathbf{1 9 8 0 - 8 9}$ & $\mathbf{1 9 9 0 - 9 9}$ & $\mathbf{2 0 0 0 - 0 5}$ \\
\hline Angola & 15 & 4 & 3 & 3 \\
Cameroon & 17 & 15 & 16 & 16 \\
Congo & 18 & 10 & 10 & 13 \\
Côte d'Ivoire & 16 & 18 & 21 & 25 \\
Equatorial Guinea & 6 & 9 & 7 & 5 \\
Gabon & 7 & 7 & 6 & 6 \\
Nigeria & 7 & 4 & 6 & 6 \\
Indonesia & 20 & 25 & 42 & 50 \\
Mexico & 53 & 30 & 39 & 33 \\
Trinidad and Tobago & 11 & 14 & 27 & 22 \\
United Arab Emirates & 4 & 9 & 19 & 28 \\
Venezuela & 6 & 7 & 18 & 17 \\
\hline
\end{tabular}

Source: Author's calculations based on UN-COMTRADE database.

${ }^{1}$ Includes fuel-based commodities; total number of product categories is 182 .

In addition, the OPAC have a comparative advantage mainly in primary commodities (Table 3). For example, Angola and Congo did not show an advantage in any manufactured product in 2005; Cameroon, Côte d'Ivoire, and Gabon had an $R C A$ greater than one in a lowskill intensive manufacture category_-veneers, plywood boards, and other worked wood products - and Nigeria in only leather and leather products.

Table 3. Sectoral Distribution of Revealed Comparative Advantage, 2005

\begin{tabular}{lcc}
\hline & Nonfuel Primary Commodities & Manufactures \\
\hline Angola & 2 & 0 \\
Cameroon & 13 & 1 \\
Congo & 8 & 0 \\
Côte d'Ivoire & 13 & 2 \\
Equatorial Guinea & 1 & 2 \\
Gabon & 4 & 1 \\
Nigeria & 2 & 1 \\
Indonesia & 21 & 23 \\
Mexico & 13 & 22 \\
Trinidad and Tobago & 7 & 6 \\
United Arab Emirates & 12 & 8 \\
Venezuela & 4 & 5 \\
\hline
\end{tabular}

Source: Author's calculations based on UN-COMTRADE database. 
Figure 4. Export Structure and Concentration, 1970-2005
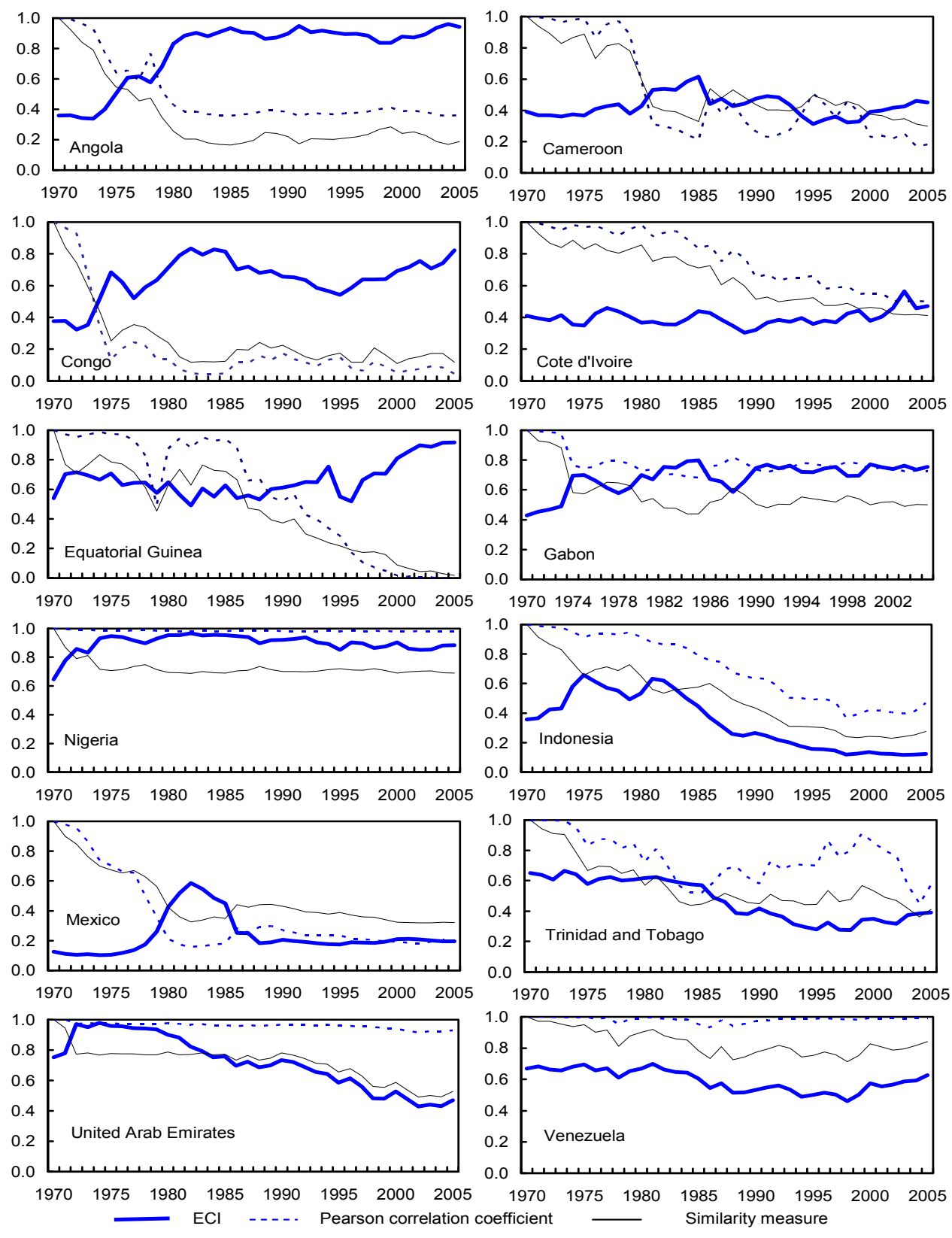

Source: Author's calculations based on UN-COMTRADE database.

Overall, OPAC have been unable to show a significant increase in their share of world nonfuel products, though trends differ by sector and country. For example, Cameroon and Nigeria recorded a significant decline in their share in world cocoa exports in the past three decades, whereas Côte d'Ivoire almost tripled its share. Similarly, while Gabon maintained its share in world exports of wood and wood products at around 1 percent, Cameroon increased its share from 0.5 percent to slightly over 1 percent. Meanwhile, Indonesia, Mexico, and the UAE increased their world share of non-fuel merchandise manifold (see Figure 5). 
Figure 5. World Share of Nonfuel Merchandise Exports, 1970-2005

(Percent)

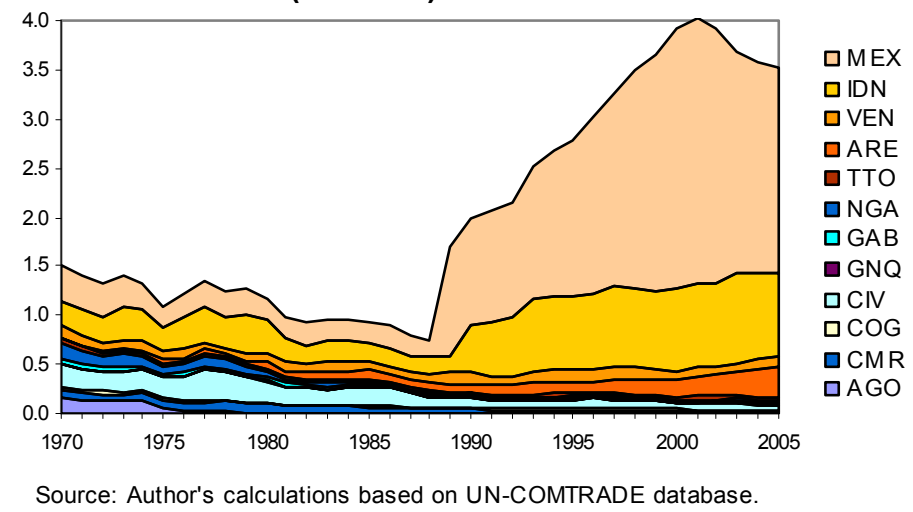

\section{Productivity, Infrastructure, and Human Capital}

Productivity is a key determinant and indicator of competitiveness. It usually refers to labor productivity measured as output produced per worker or per worker-hour. Since accurate data on labor productivity is difficult to obtain, especially for the African economies, it is often proxied by real GDP per capita or per worker. However, the measures of productivity based on real GDP may be misleading for oil rich economies since they do not isolate the output or productivity of the non-oil sector. Hence, we also compute real non-oil GDP per capita for the OPAC and comparator countries (Figure 6). ${ }^{19}$ The indicators reveal broadly similar patterns: on average, the OPAC have much lower labor productivity than the other countries. However, among the OPAC Gabon has the highest and Angola, Chad, and Nigeria have the lowest values for real GDP per capita and per worker, and real non-oil GDP per capita.

Figure 6. Real GDP and Non-oil GDP per Capita (US\$ thousands), 1970-2006 ${ }^{1}$
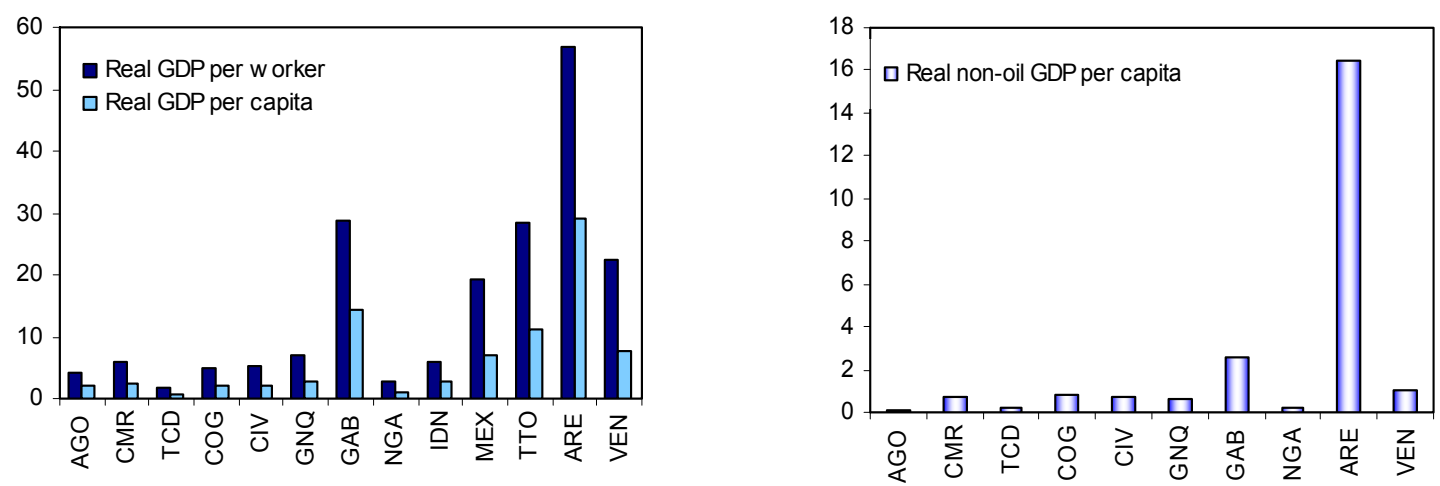

Source: Author's calculations based on Heston et al. (2006) and World Economic Outlook database.

${ }^{1}$ Real GDP per worker is the average for 1970-2003, except for Angola where data are available for 2000 only; Real GDP per capita is the average for 1970-2004; Real non-oil GDP per capita is the average for 2000-06.

\footnotetext{
${ }^{19}$ Following Ramirez and Tsangarides (2007), we construct another measure of productivity that is the ratio of a country's real GDP per capita to the weighted average of the real GDP per capita of its main trading partners. The computed values of the index present a fairly similar picture to Figure 5.
} 
Since productivity itself is determined by such factors as technology, infrastructure, human capital, and the institutional and macroeconomic environment, it is important to complement the analysis by examining its determinants. These factors are also important because they may impact competitiveness through other channels, for example, reduced production costs, product quality improvement, investment promotion, and trade facilitation. Moreover, the state of these factors reflects the policy choices made by the governments over the years.

The information, communication, and technology (ICT) indicators compiled by the World Bank show that the UAE outperforms the other countries in ICT access, quality, and affordability (Table 4). ${ }^{20}$ The OPAC lag far behind the other oil producers, with Angola and Chad having the worst and Gabon the best ICT infrastructure of the eight countries. Most OPAC perform poorly even compared to the average for the entire SSA region, especially in ICT availability.

Transport infrastructure in OPAC, indicated by paved roads as a percentage of the total road network, is also dismal. On average, only about 11 percent of the roads are paved-below the average for SSA and much below that of the other oil exporters.

Human capital appears to be another concern for the OPAC (see Table 5). The OPAC rank among the lowest in the world on the Human Development Index (HDI), compiled by the United Nations Development Program (UNDP). Gabon has the highest HDI value of the group; with an adult literacy rate of 84 percent and a combined (primary, secondary, and tertiary) gross enrollment ratio of 72.4 percent, it ranks 119 out of 177 countries. In contrast, Chad and Côte d'Ivoire have very low literacy and enrollment rates.

Table 4. ICT and Transport Infrastructure Indicators for Selected Economies, $2005^{1}$

\begin{tabular}{|c|c|c|c|c|c|c|c|c|c|c|c|c|c|c|}
\hline & $\begin{array}{c}\text { AG } \\
0\end{array}$ & $\begin{array}{l}\mathbf{C M} \\
\mathbf{R}\end{array}$ & TCD & $\begin{array}{c}\text { CO } \\
\mathbf{G}\end{array}$ & CIV & $\begin{array}{c}\mathbf{G N} \\
\mathbf{Q}\end{array}$ & $\begin{array}{c}\text { GA } \\
\text { B }\end{array}$ & $\begin{array}{c}\text { NG } \\
\text { A }\end{array}$ & SSA & IDN & $\begin{array}{c}\mathrm{ME} \\
\mathbf{X}\end{array}$ & TTO & ARE & $\begin{array}{l}\text { VE } \\
\text { N }\end{array}$ \\
\hline \multicolumn{15}{|l|}{ ICT } \\
\hline \multicolumn{15}{|c|}{ Access (per 1,000 people) } \\
\hline $\begin{array}{l}\text { Telephone main } \\
\text { lines }\end{array}$ & 6 & 6 & 1 & 4 & 14 & 20 & 28 & 9 & 17 & 58 & 189 & 248 & 273 & 136 \\
\hline Mobile subscribers & 69 & 138 & 22 & 123 & 121 & 192 & 470 & 141 & 125 & 213 & 460 & 613 & 1,000 & 470 \\
\hline Internet users & 11 & 15 & 4 & 13 & 11 & 14 & 48 & 38 & 29 & 73 & 181 & 123 & 308 & 125 \\
\hline Personal computers & 2 & 10 & 2 & 4 & 15 & 14 & 33 & 7 & 15 & 14 & 136 & 79 & 197 & 82 \\
\hline \multicolumn{15}{|l|}{ Quality } \\
\hline $\begin{array}{l}\text { Telephone faults } \\
\text { (per } 100 \text { main lines } \\
\text { per yr.) }\end{array}$ & 36.9 & $\ldots$ & $52^{*}$ & $\ldots$ & 81 & $\ldots$ & 45 & 20.6 & 48 & $\underset{*}{16.0}$ & 1.8 & $\ldots$ & 0.3 & $2^{*}$ \\
\hline $\begin{array}{l}\text { Internet bandwidth } \\
\text { (bits per person) }\end{array}$ & 0 & 1 & 0 & 0 & 3 & 33 & 145 & 1 & 2 & 7 & 110 & 375 & 923 & 51 \\
\hline \multicolumn{15}{|c|}{$\begin{array}{c}\text { Affordability (US\$ per } \\
\text { month) }\end{array}$} \\
\hline Fixed line & 11.9 & 9.3 & 16.9 & $\ldots$ & 28 & $\ldots$ & 32.4 & $\ldots$ & 14 & 5.8 & 16 & 7 & 17.4 & $\ldots$ \\
\hline Mobile & 11.9 & 16.5 & 13.3 & 11 & 22 & $\ldots$ & 14.7 & 10.6 & 12 & 4.3 & 14 & 6.7 & 4.1 & 1.2 \\
\hline Internet & 34.3 & 44.6 & 86.3 & 84.5 & 67 & 32.7 & 40.1 & 50.4 & 45 & 17 & 20 & 13 & 13.1 & 43 \\
\hline \multicolumn{15}{|l|}{ Transport } \\
\hline $\begin{array}{l}\text { Paved roads (\% of } \\
\text { total roads) }\end{array}$ & 10.4 & 11.7 & 0.8 & 9.3 & 9.3 & $\ldots$ & 9.1 & 25.6 & 14.7 & 51.9 & 35.7 & 49.6 & 98.8 & 35.4 \\
\hline
\end{tabular}

Source: ICT at a Glance Tables and World Development Indicators 2007.

1 ... indicates data not available; * indicates that reported statistic is for 2000; $A G O=A n g o l a ; C M R=C a m e r o o n ; T C D=C h a d ; C O G=C o n g o(R e p$. of); $\mathrm{CIV=Côte} \mathrm{d'Ivoire;} \mathrm{GNQ=Equatorial} \mathrm{Guinea;} \mathrm{GAB=Gabon;} \mathrm{NGA=Nigeria;} \mathrm{IDN=Indonesia;} \mathrm{MEX=Mexico;} \mathrm{TTO=Trinidad} \mathrm{and} \mathrm{Tobago;} \mathrm{ARE=United}$ Arab Emirates; VEN=Venezuela.

${ }^{20}$ Source: www.worldbank.org/ict/ 
Table 5. OPAC Human Development Indicators, 2005

\begin{tabular}{lccccc}
\hline & HDI & HDI Rank & $\begin{array}{c}\text { Adult Literacy Rate } \\
(\% \text { aged 15+) }\end{array}$ & $\begin{array}{c}\text { Gross Enrolment for Primary, } \\
\text { Secondary, and Tertiary Levels (\%) }\end{array}$ & $\begin{array}{c}\text { Life Expectancy } \\
\text { Index }\end{array}$ \\
\hline AGO & 0.45 & 162 & 67.4 & $25.6^{*}$ & 0.28 \\
CMR & 0.53 & 144 & 67.9 & 62.3 & 0.41 \\
TCD & 0.39 & 170 & 25.7 & 37.5 & 0.42 \\
CGO & 0.55 & 139 & 84.7 & 51.4 & 0.48 \\
CIV & 0.43 & 166 & 48.7 & $39.6^{*}$ & 0.37 \\
GNQ & 0.64 & 127 & 87.0 & 58.1 & 0.42 \\
GAB & 0.68 & 119 & 84.0 & $72.4^{*}$ & 0.52 \\
NGA & 0.47 & 158 & 69.1 & 56.2 & 0.36 \\
SSA & 0.49 & NA & 60.3 & 50.4 & 0.41 \\
IDN & 0.73 & 107 & 90.4 & 68.2 & 0.75 \\
MEX & 0.83 & 52 & 91.6 & 75.6 & 0.84 \\
TTO & 0.81 & 59 & 98.4 & 64.9 & 0.74 \\
ARE & 0.87 & 39 & 88.7 & $59.9^{*}$ & 0.89 \\
VEN & 0.79 & 74 & 93.0 & $75.5^{*}$ & 0.80 \\
\hline
\end{tabular}

Source: UNDP, Human Development Report 2007-08 (http://hdr.undp.org/en/statistics/).

${ }^{1}$ Literacy estimates from censuses and surveys conducted between 1995 and 2005. Due to differences in methodology and timeliness of data, comparisons between countries should be made with caution.

${ }^{2}$ Life expectancy index is the normalized value of life expectancy at birth.

${ }^{*}=$ data for a year other than 2005.

\section{Institutional Quality}

To assess OPAC's structural competitiveness and analyze their policy initiatives, it is important to examine the overall investment climate based on the quality of institutions and governance. We do so by examining different but closely linked and well-known perception-based measures of institutional quality that are collected through surveys and indicate the structural advantage and ease of conducting business in one economy relative to others.

\section{Doing business indicator}

The Doing Business Indicator (DBI) compiled by the World Bank is an objective measure that identifies institutional and political bottlenecks in starting and conducting business activities. ${ }^{21}$ In 2007, the OPAC have an average DBI rank of 155 (out of 178 countries), worse than SSA and all other oil producers except Venezuela (Figure 7). Nigeria - the best OPAC performerranks 108, followed by Gabon, Cameroon, Côte d'Ivoire, Equatorial Guinea, Angola, Chad, and Congo. Among the other oil exporters, Mexico performs the best at 44, followed by Trinidad and Tobago and the UAE.

In terms of the subcategories of DBI, the OPAC lag behind, especially in ease of obtaining credit, dealing with licenses, trading across borders, and protecting investors. For example, on average, it takes the OPAC about 40 days to export goods, compared to 21 in Indonesia, 17 in Mexico, 14 in Trinidad and Tobago, and 13 in the UAE. Similarly, the number of days required to import goods into OPAC is also almost double that for the other oil producers.

\footnotetext{
${ }^{21}$ The DBI is based on 10 indices that evaluate ease of starting/closing business, getting licenses, hiring labor, registering property, paying taxes, getting credit, protecting investors, trading, and enforcing contracts. See the Appendix for the detailed breakdown of the DBI by subcategories.
} 
Figure 7. DBI Ranking for OPAC and Selected Economies, $2007^{1}$
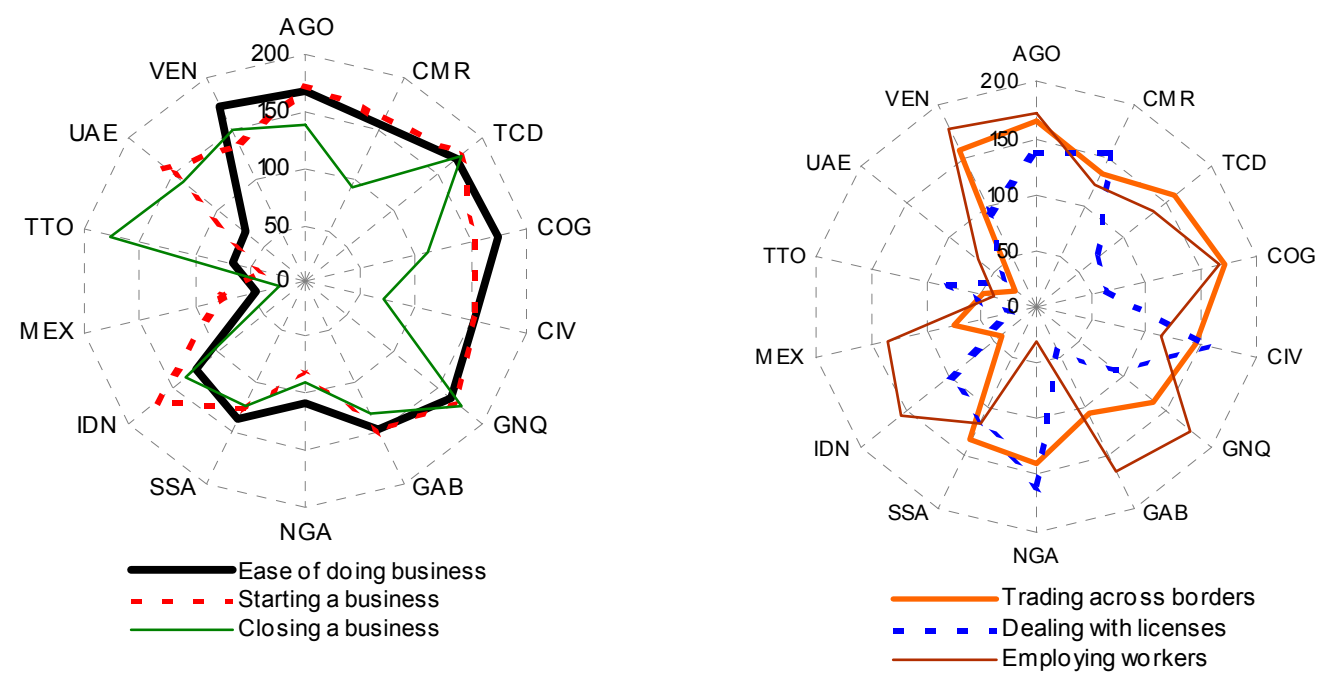

Source: Doing Business database (http://www.doingbusiness.org).

${ }^{1}$ The axis represent the ranks from 0 to 200; where a lower rank indicates better performance and greater ease in doing business.

\section{World governance indicators}

The World Governance Indicators (WGIs) prepared by the World Bank cover six dimensions of governance and institutions: voice and accountability, regulatory quality, rule of law, control of corruption, political stability, and government effectiveness. Figure 8 plots the percentile ranks of the OPAC and comparator oil producers for each governance indicator for the entire period. On average, the OPAC perform poorly on all six indicators compared to the SSA and other oil producers except Venezuela. Among the OPAC, Gabon ranks highest in five of the six governance indicators, whereas Equatorial Guinea, Côte d'Ivoire, and Chad have the lowest percentile ranks in almost all cases (rarely rising above the $10^{\text {th }}$ percentile). ${ }^{22}$ Among the other oil producers, Mexico, Trinidad and Tobago and the UAE have the highest percentile ranks. Indonesia performs well on government effectiveness, voice and accountability, and regulatory quality, but Venezuela lags in all indicators.

\footnotetext{
${ }^{22}$ Over the years, Angola is the only OPAC that does not exhibit a drop in any of the six WGIs since 1998. In contrast, Chad and Côte d'Ivoire fell in rank in every indicator, and Gabon's performance deteriorated in all but the political stability indicator. Nigeria's rank improved in voice and accountability, government effectiveness, and the rule of law, but dropped in the others.
} 
Figure 8. WGI for OPAC and Selected Economies, 1998-2006

(Percentile rank) $^{1}$
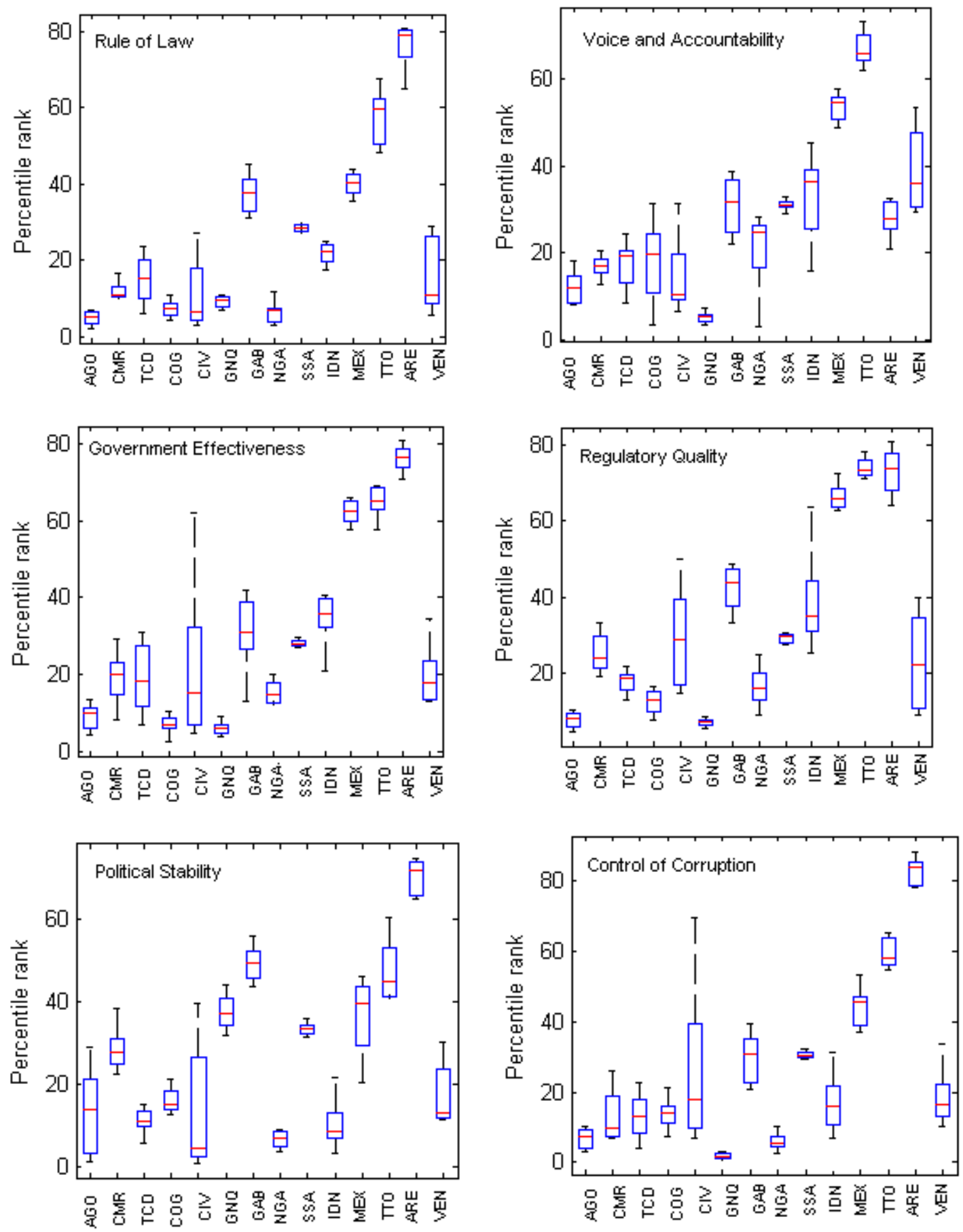

Source: Worldwide Governance Indicators (www.worldbank.org/wbi/governance/govdata/).

${ }^{1}$ Lines for each box reflect the lower quartile, median, and upper quartile values. The lines extending from each end of the box show the extent of the rest of the data. Outliers have been excluded. 


\section{Global competitiveness index}

The World Economic Forum's Global Competitiveness Index (GCI) is a broader measure than either the DBI or the WGI that provides a comprehensive view of factors crucial for enhancing competitiveness. ${ }^{23}$ It is based on nine pillars: institutions, infrastructure, economy, health and primary education, higher education and training, market efficiency, technological readiness, business sophistication, and innovation, which are grouped into three categoriesbasic requirements, efficiency enhancers, and innovation and sophistication factors - each relatively more relevant for a particular stage of economic development. ${ }^{24}$

The basic requirements index groups together the pillars most critical for countries in the factor-driven stage of development (infrastructure, institutions, macroeconomy, health, and primary education); the efficiency enhancers index groups the pillars critical for countries in the efficiency-driven stage (higher education and training, market efficiency, technological readiness); and the innovation and sophistication index comprises pillars important for countries in the innovation-driven stage (business sophistication and innovation). Figure 9 shows the rankings (out of 125 countries) of the oil-producers for the GCI and its subindices. ${ }^{25}$ The UAE is the best performer as a whole and in all the subcategories, followed by Indonesia and Mexico. Chad and Angola have the lowest scores and rank $123^{\text {rd }}$ and $125^{\text {th }}$, respectively.

Figure 9. GCI Rankings for Selected Economies, 2006
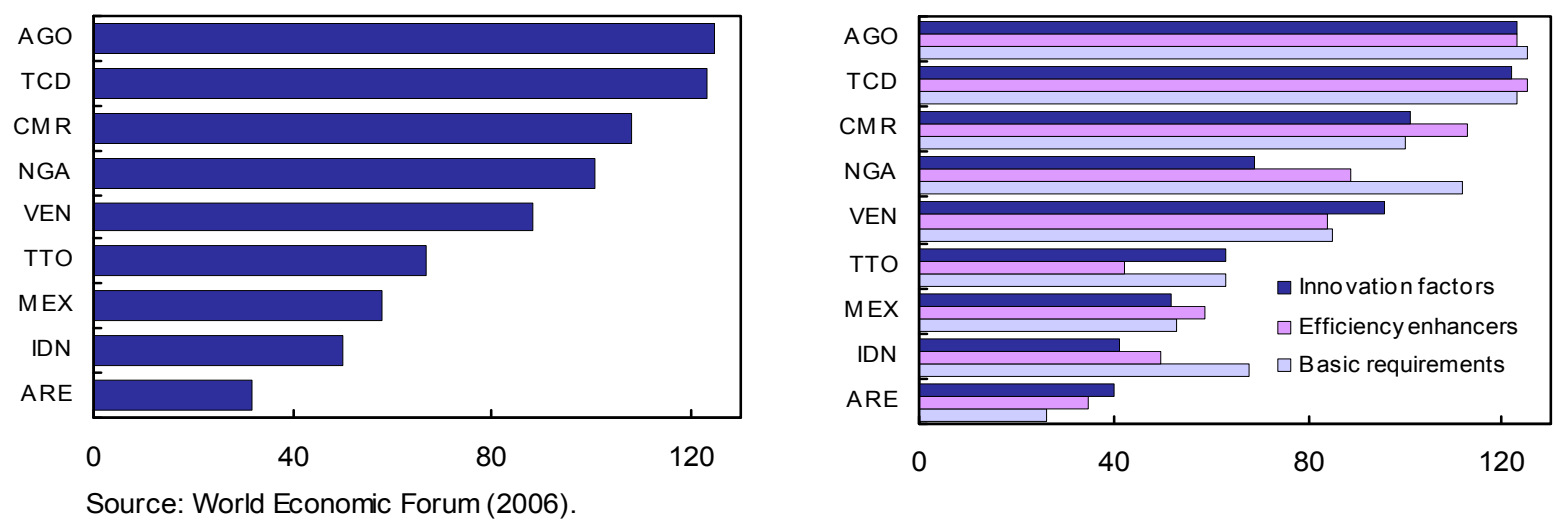

Overall, OPAC's structural competitiveness, as reflected by the reviewed indicators, seems to be far from satisfactory. The development of the non-oil sector, institutions, and physical and human capital infrastructure lags behind their oil rich counterparts in other regions of the world. For some OPAC, like Angola and Côte d'Ivoire, political instability and conflict may

\footnotetext{
23 The GCI were developed by Xavier Sala-i-Martin and Elsa Artadi for the World Economic Forum.

${ }^{24}$ The three stages of development identified by the GCI are factor-driven (per capita income below \$2,000); efficiency-driven (per capita income between $\$ 3,000-9,000$ ); and innovation-driven (per capita income above $\$ 17,000)$. Countries that do not fit into a category are considered as in transition from one stage to the other.

${ }^{25}$ The GCI is unavailable for Gabon, Equatorial Guinea, and Cote d'Ivoire.
} 
have played a significant role in hampering the development of these features. ${ }^{26}$ That said, it is interesting to note the high correlation between indicators, such as infrastructure and institutional quality with the development of the non-oil sector, across countries. For example, Indonesia, Mexico and the United Arab Emirates have relatively strong structural competitiveness indicators, which matches the export performance of their non-oil sector in terms of diversification, increased world share in non-fuel merchandise, and a revealed comparative advantage in a larger number of product categories. In contrast, the OPAC and, among the comparator countries, Venezuela appear to have an overall weak investment climate and a weak non-oil tradable sector. In what follows, we explore this issue in detail and formally investigate the importance of structural factors, particularly, institutional quality, in determining the external competitiveness of the non-oil sector in these economies.

\section{INSTITUTIONAL QUALITY AND EXPORT COMPETITIVENESS}

While some may argue that oil abundance and the onset of Dutch disease are to blame for OPAC's weak non-oil export performance, the comparative analysis suggests that structural factors, such as institutions and infrastructure, may have inhibited the integration of OPAC in international trade activity. Hence, while Indonesia and the UAE were able to overcome the adverse effects of the oil boom and promote non-oil exports, the OPAC economies did not recover. This observation is supported by earlier studies which note that SSA has been trading below its potential in recent years due to policy and institutional factors (IMF, 2002; Carey, Gupta, and Jacoby, 2007). ${ }^{27}$

The importance of institutions in determining the extent of the impact of oil abundance on non-oil trade is highlighted when, as a preliminary step, we plot the net non-oil exports of world economies against different measures of oil abundance (Figure 10). Non-oil exports seem to be negatively related with oil abundance regardless of the measure used. However, when countries are grouped by institutional quality, the negative relationship between net oil and non-oil exports is more pronounced for net oil exporters with low-quality institutions. ${ }^{28}$ This pattern suggests that institutional quality may be an important factor in determining the export performance of the non-oil sector in oil-rich economies. ${ }^{29}$

\footnotetext{
${ }^{26}$ Angola endured almost 40 years of political turbulence that began from the war of independence (1961-75) and was followed by a civil war (1975-2002). Côte d'Ivoire faced political instability as a result of two coups in 1999 and 2001, and the ensuing civil war in 2002.

${ }^{27}$ IMF (2002) and Carey, Gupta, and Jacoby (2007) use the gravity model of trade (explained in Section IV.A) to estimate SSA's trade potential by comparing predictions from the model to actual trade values. Using a similar methodology for the OPAC, we find that it is an under performer (see Tables B3 and B4). OPAC's performance is similar to SSA as a whole: both switched from modestly overtrading in 1970-89 to undertrading in 1990-2005. In contrast, the performance of Indonesia, Mexico, and the UAE has strengthened.

${ }^{28}$ Low institutional quality refers to a below-median WGI score, where the latter is constructed by taking the average of the scores of the six components of WGI.

${ }^{29}$ As will be evident in section IV.C, this basic result holds even when we control for other factors.
} 
Figure 10. Oil Abundance and Non-oil Exports ${ }^{1}$
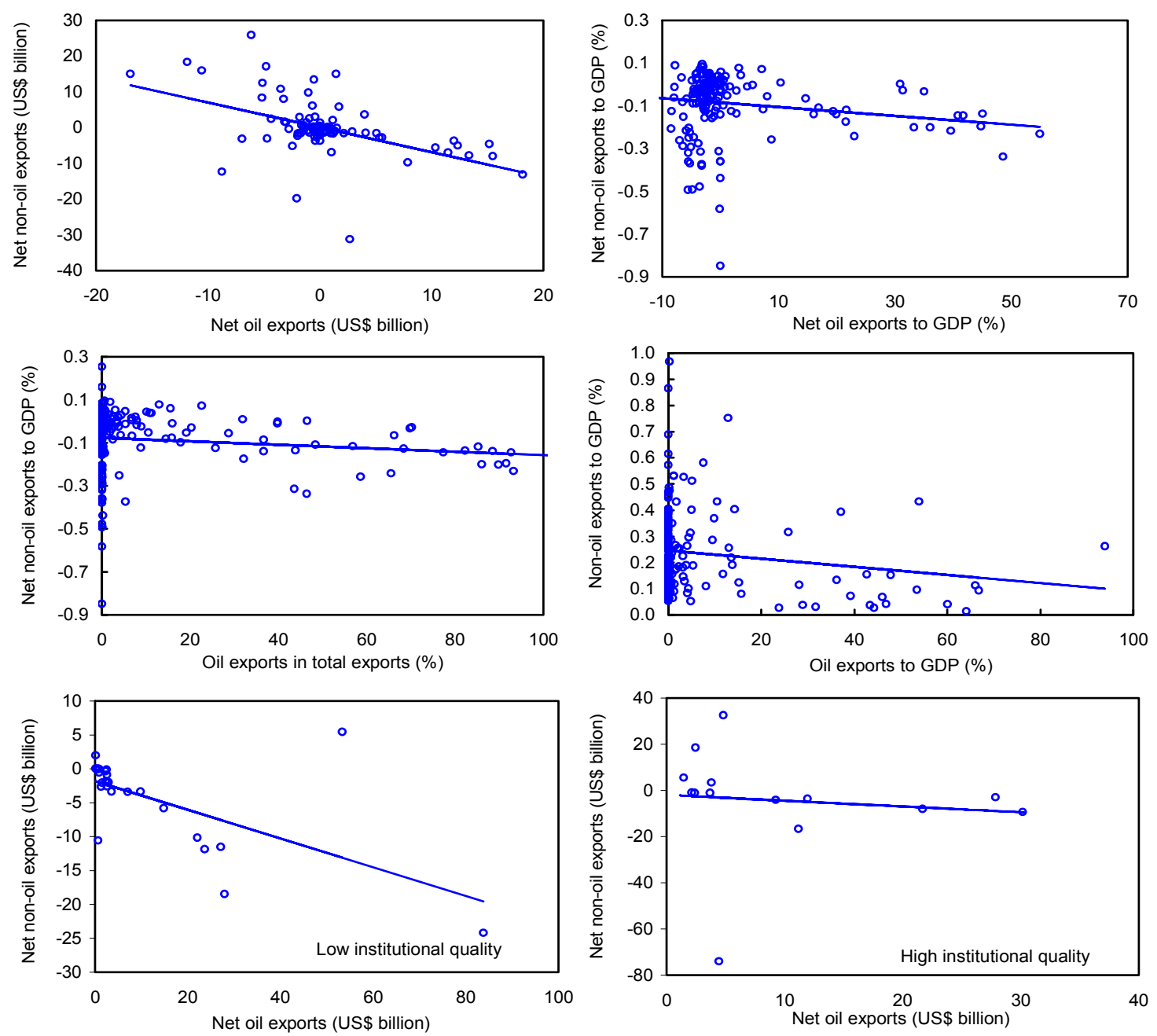

Source: Author's calculations based on the WEO database and the World Governance Indicators.

$1 /$ Extreme outliers have been removed from the figures; low institutional quality refers to below median (average) score for the six World Governance Indicators.

However, while the importance of institutional quality for promoting trade is well established both theoretically and empirically, its significance in explaining the divergent experiences of oil-rich economies has not been explored. ${ }^{30} \mathrm{We}$ argue that the significance of institutions in promoting trade may be amplified in oil-abundant economies because natural resources test the institutional arrangements of economies, so that only countries with producer-friendly institutions and effective management of oil revenues benefit from oil abundance (Mehlum, Moehne, and Torvik, 2006). ${ }^{31}$ Thus, there may not be an unconditional negative relationship between oil abundance and non-oil trade, and institutions could play a decisive role.

\footnotetext{
${ }^{30}$ See, for example, Anderson and Marcouiller (2002) and Francois and Manchin (2007) for a detailed discussion of the impact of institutions on trade.

${ }^{31}$ In studies investigating the resource curse hypothesis, Leite and Weidmann (1999) and Sala-i-Martin and Subramanian (2003) show that institutions are negatively affected by natural resource abundance.
} 


\section{A. Methodology}

To investigate the extent to which institutional arrangements explain the performance of nonoil exports in oil-rich economies, we employ the gravity model of trade. The gravity model, proposed by Tinbergen (1962), is a popular tool in international trade analysis that uses the concept of gravitational force to explain trade flows $(T)$ between two countries, $i$ and $j$, as being directly proportional to their economic sizes $(M)$ and inversely proportional to the distance $(D)$ between them and to other obstacles to trade:

$T_{i j}=G * \frac{\left(M_{i}^{a} * M_{j}^{b}\right)}{D_{i j}^{c}}$

Though simply specified, gravity models have performed extremely well empirically; and are often used to predict both total trade (exports and imports) flows between countries and oneway flows (exports or imports). The initial criticism that these models lacked a proper theoretical foundation has been met by numerous studies that use different approaches to establish their theoretical justification (Anderson, 1979; Bergstrand, 1985; Deardorff, 1998). In recent years, the models have also been used to examine determinants of trade other than distance and size, such as trade agreements, currency unions, common language, colonial ties, trade policies, nontariff barriers, infrastructure, and institutions. Thus, in line with recent empirical literature, we estimate the following benchmark specification:

$$
\begin{aligned}
& \ln \left(X_{i j t}\right)=b_{0}+b_{1} \ln \left(Y_{i t}\right)+b_{2} \ln \left(Y_{j t}\right)+b_{3} \ln \left(D I S T_{i j}\right)+b_{4} F T A_{i j}+b_{5} L_{A N G_{i j}}+b_{6} B O R D E R_{i j}+b_{7} L_{A N D_{i j}}+ \\
& b_{8} I S L A N D_{i j}+b_{9} C O L_{i j}+b_{10} C U R C O L_{i j}+\varepsilon_{i j t},
\end{aligned}
$$

where $X_{\mathrm{ijt}}$ represents real non-oil exports from country $i$ to country $j$ in time period $t .^{32} Y$ denotes real GDP, DIST is the geographical distance between the trading partners, and FTA, $L A N G, B O R D E R, C O L$, and CURCOL are dummy variables that equal one if the trading partners share a free trade agreement, language, border, historical colonial ties, or current colonial ties, respectively, and are equal to zero otherwise. LAND and ISLAND indicate the landlocked and island countries in the trading pair, respectively, and $\varepsilon_{\mathrm{ijt}}$ is the error term, assumed to be independently and normally distributed $\left(\varepsilon_{\mathrm{ij}} \sim \mathrm{N}(0, \sigma)\right)$.

Anderson and van Wincoop (2001) show that in equilibrium, bilateral trade depends on the relative prices of the exporting and importing countries, which themselves depend on the existence of trade barriers or "multilateral resistance" from other countries. Omitting relative prices could, therefore, bias the estimates. To control for this bias, we introduce country-pair fixed effects in the model. ${ }^{33}$ Further, since panel data is being used, we also take into account any time-varying effects by introducing yearly dummy variables in equation (5).

\footnotetext{
${ }^{32}$ Gravity models may also be used to explain sectoral export flows. See, for example, Bergstrand (1989), Feenstra, Markusen, and Rose (2001), and Stijns (2003).

${ }^{33}$ In the fixed-effects estimations, time invariant variables (such as those representing geographical, cultural, and historical characteristics) drop out of the estimation.
} 
To address the primary question of whether institutions affect the export competitiveness of the non-oil tradable sector in the presence of oil resources, we augment the benchmark specification by including variables reflecting institutional quality (INS), oil abundance $(O I L)$, and an interaction term between oil abundance and institutional quality of the exporting country. Further, since exports are estimated to be significantly affected by the quality of infrastructure $(I N F)$, we also control for the latter and estimate the following augmented specification with country-pair fixed effects $\left(\mu_{\mathrm{ij}}\right)$ :

$\ln \left(X_{i j t}\right)=b_{0}+b_{1} \ln \left(Y_{i t}\right)+b_{2} \ln \left(Y_{j t}\right)+b_{3} F T A_{i j}+b_{4} I N S_{i}+b_{5} O I L_{i}+b_{6} O I L_{i} * I N S_{i}+b_{7} I N F_{i}+b_{8} \mu_{i j}+\varepsilon_{i j t}$,

The coefficient of interest is $b_{6}$ : if institutional quality indeed determines the extent of non-oil export competitiveness, the estimated value for $b_{6}$ should be positive. This would imply that better institutions in the presence of oil abundance lead to greater non-oil exports. To define oil abundance, we use share of oil exports in total exports as a proxy. ${ }^{34}$ Infrastructure is represented by main telephone lines per 1,000 inhabitants and institutions by three indices compiled by Political Risk Services (PRS): bureaucratic quality, government stability, and corruption. ${ }^{35}$ We normalize the indices to a range of 0 to 1 where a higher value indicates better institutions. Further, since the three PRS indices tend to be highly correlated and create the problem of multicollinearity if included together, we apply principal component analysis and retain the first principal component (which accounts for over 60 percent of the total variance) as a composite measure of institutional quality. ${ }^{36}$

\section{B. Data Issues}

The data for the analysis have been compiled from multiple sources. ${ }^{37}$ They form an unbalanced panel dataset that covers 190 industrial and developing countries for 1970-2006. Annual bilateral data for non-oil exports are obtained from the UN-COMTRADE database. ${ }^{38}$ Data on real GDP (in 2000 US dollars), real GDP per capita (in 2000 US dollars), population, and infrastructure are compiled from the World Bank's World Development Indicators (WDI) 2007. Institutional quality indices have been taken from the Political Risk Services Group and the World Bank WGI dataset. The source for information on distance, colonial

\footnotetext{
${ }^{34} \mathrm{We}$ also use oil exports as a share of GDP and a dummy variable equal to 1 if the country is a net exporter of oil and 0 otherwise as alternate proxies in the sensitivity analysis, but the results do not differ significantly. They are available upon request.

${ }^{35}$ The choice of proxies for infrastructure and institutions is motivated by data availability. We prefer to use PRS indices over WGI because the former is available for a longer period (1985-2006). The WGI cover 1996-2006 (with gaps), and are used as alternative indicators in the sensitivity analysis.

${ }^{36}$ To isolate the impact of institutions and infrastructure from that of real per capita income (the former tend to be highly positively correlated with the latter), we follow Francois and Manchin (2007) and regress them on (logs of) per capita income and population. The residuals obtained from the estimations are used in equation (6).

${ }^{37}$ See Appendix B for a description of data sources and summary statistics for the variables of interest.

${ }^{38}$ Non-oil exports are expressed in real US dollars using the non-oil export deflator index $(2000=100)$ for each exporter from the World Economic Outlook 2007. The US consumer price index for all urban consumers (1982$84=100)$ is used as an alternate deflator in the sensitivity analysis but does not change the results much.
} 
ties, and language is the CIA World Factbook 2004, and for free trade agreements is Tsangarides et al. (2007).

We estimate the benchmark and augmented gravity specifications for two samples: the world and SSA. The first sample covers all countries for which the required data are available. The second sample comprises those trading pairs where the exporting country is restricted to be in SSA but its trading partner may or may not be in the region.

\section{Results}

Table 6 gives the results for the gravity model estimated using the world sample. Columns (1) and (3) present the results for the benchmark specification using pooled ordinary least squares (OLS) and the fixed-effects estimation techniques, respectively. ${ }^{39}$ The magnitude and signs of the coefficients obtained from both estimations are plausible and in line with those reported in earlier studies. In the OLS estimation, non-oil exports are influenced positively by the size of the economy and negatively by distance between the origin and destination countries. On average, free trade agreements, colonial ties, common language, common border, and access to the sea positively affect exports. However, the magnitude of the estimated coefficients for the time-variant variables (real GDP, currency unions, and free trade agreements) changes notably when fixed effects are included in the equation, indicating a bias in the OLS estimates.

Column (3) presents the results when (log of) oil export share in total exports is included in the model. Clearly, the oil richness of the exporting country has a significantly negative effect on its non-oil exports: increasing the share of oil in total exports by 10 percent decreases real non-oil exports by about 0.4 percent. This finding, which supports the Dutch disease hypothesis, suggests that on average oil-rich countries trade less than non-oil-rich countries. In Columns (4) to (6) the indices reflecting control of corruption, bureaucratic quality, and government stability are included in the model along with the indicator for infrastructure quality and the respective interaction term. In each case, and consistent with the findings of earlier studies, the estimated coefficients of infrastructure and institutions are significantly positive. A 10 percent improvement in infrastructure, for instance, is estimated to improve non-oil exports by 1.0-1.6 percent. Of the institutional features, bureaucratic quality appears to have the largest effect, followed by control of corruption, and then government stability. Importantly, the interaction term for control of corruption and bureaucratic quality is strongly positive, albeit small in size. This finding is reinforced when we use the composite measure (principal component) for the three indices (defined as institutional quality), as in column (7). The impact of both institutional quality and its interaction term is strongly positive, confirming our preliminary finding that oil abundance enhances non-oil exports if a country has good institutions.

\footnotetext{
39 The benchmark specification is also estimated using the random effects model. However, the Hausman statistic (reported in the last row of Table 6) indicates that fixed effects is the preferred specification.
} 
Table 7 reports the estimation results for the SSA sample. The effect of oil abundance on non-oil exports is in line with that obtained for the world sample but, interestingly, the marginal effect of infrastructure and the composite measure for institutional quality on nonoil exports in this case is much larger. Of the individual indices, control of corruption has the largest effect, followed by bureaucratic quality. Since corruption control is closely related to oil revenue management, this finding also reflects the importance of prudent oil revenue spending for the non-oil sector. The estimated coefficient for government stability is insignificant, but its interaction term is significantly positive, indicating that oil abundance promotes non-oil exports when the government is stable.

In Table 8, the findings are confirmed using a slightly different approach. The effect of oil abundance on non-oil exports is examined by grouping all countries into two groups (low and high) based on institutional quality scores. ${ }^{40}$ Results for the world and SSA samples show that oil abundance has a relatively pronounced effect on non-oil exports if institutions are fragile: a 10 percent increase in the share of oil exports decreases real non-oil exports by about 0.4 percent in the low quality group in both samples. The effect of oil abundance in the high-quality group is small but significant for the world, but it is insignificant for SSA. This may be because in the SSA sample, all the major oil exporters belong to the low-quality institutions category.

\section{Sensitivity Analysis}

Estimation of the gravity model raises methodological concerns that have been extensively discussed in the literature. ${ }^{41}$ Foremost is the issue of a large number of zero-trade observations in bilateral trade datasets. Using the log-linear version of the gravity equation, as in equations (5) and (6), implies dropping all zero observations, which typically constitute about one-third of the dataset. Given that the value of trade flows between some pairs of countries, especially small countries, tends to be zero (either because they did not trade or because of rounding errors and missing observations), this may lead to a sample selection problem and produce inconsistent estimates.

Various approaches have been proposed to deal with the issue, such as the Tobit method and the Poisson pseudo maximum likelihood (PPML) approach. ${ }^{42}$ Santos Silva and Tenreyro (2006) argue that employing the conventional Tobit technique to estimate a gravity model in the presence of heteroskedasticity may produce inconsistent estimates. They therefore

\footnotetext{
${ }^{40}$ Countries below the median score of the composite measure, institutional quality, fall in the low-quality category.

${ }^{41}$ See, for example, Baldwin (2006).

${ }^{42}$ Heckman's two stage selection model is another way to deal with zero trade observations. However, the main challenge in implementing the Heckman method is the specification of instruments for the selection (first stage) equation (Carey, Gupta, and Jacoby, 2007). This is an important issue in panel datasets where the availability of data for the chosen instruments is often a concern.
} 
propose using the PPML approach, which takes into account the zero observations (since it uses actual rather than log trade values), but also produces consistent estimates in the presence of heteroskedasticity by underweighting the observations with larger variances. ${ }^{43}$

We estimate the augmented gravity model using the PPML method as a robustness check. The results (reported in Table B5) show that the signs and significance of the estimated coefficients do not change, but the size of the marginal effect falls for most variables. The drop in the magnitude of the estimated coefficients may be the outcome of including the zero observations: excluding zero values tends to drive elasticity upward, and including them drives it downward.

Second, we address the issue of bias stemming from the correlation of any omitted variables with the explanatory variables in the gravity model. Most research attempts to control for this source of bias by introducing country-specific effects in cross-section and panel estimations. However, because there is a time-series element to the potential bias that may not be eliminated by the inclusion of simple country-specific effects, we include country-pair specific effects in all estimations. We also estimate the gravity model using separate fixed effects for the exporting and the importing countries. This has no effect whatsoever on the signs and significance of the estimated coefficients in all specifications.

Third, another concern pertaining to the gravity model is that it does not explicitly account for the comparative advantages of the trading partners. To address this issue, we follow Ciuriak and Kinjo (2006), and include a trade specialization variable, defined as net exports (exports less imports) relative to total trade (exports and imports), for the non-oil sector of the exporting country. The variable ranges from 1 (the country exports only) to -1 (the country imports only). The inclusion of this variable has no effect on the magnitude or significance of the impact of institutions or infrastructure on the export performance of the non-oil sector. ${ }^{44}$

Finally, we use alternative proxies for both oil abundance (such as oil exports as a share of GDP plus a dummy variable equal to 1 if the country is a net oil exporter and 0 otherwise) and institutional quality (the average score for the six dimensions of WGI), as well as a different deflator (US CPI for urban consumers) to express non-oil exports in real terms. We also include real per capita income and population as additional measures for size of the economy in the model specification. However, using the alternative variables does not change the main findings; on average oil abundance has a negative effect and institutional quality determines the extent to which oil richness affects real non-oil exports.

\footnotetext{
${ }^{43}$ They further argue that the PPML has a functional form that is superior to the log-linear gravity model. This is because Jensen's inequality, which implies that even if the expected value of the error term obtained from equation (4) is zero, $\mathrm{E}\left[\log X_{\mathrm{ij}} \mid Z_{\mathrm{ij}}\right]$ is not essentially equivalent to $\exp \left(\mathrm{E}\left[X_{\mathrm{ij}} \mid Z_{\mathrm{ij}}\right]\right)$, can have important implications for log-linear models; if the error term is heteroskedastic, with the variance depending upon the regressors, the parameters estimated by OLS can be severely biased.

${ }^{44}$ The results of this specification are not included for brevity reasons but are available upon request.
} 
Table 6. Institutions and Real Non-oil Exports: Estimates for the World Sample

\begin{tabular}{|c|c|c|c|c|c|c|c|}
\hline \multirow[t]{2}{*}{ Estimation } & Pooled & Fixed Effects & Fixed Effects & Fixed Effects & Fixed Effects & Fixed Effects & Fixed Effects \\
\hline & (1) & (2) & (3) & (4) & (5) & (6) & (7) \\
\hline \multirow[t]{2}{*}{ Log real GDP (origin) } & $1.13^{* * *}$ & $1.31^{* * *}$ & $1.33^{* * *}$ & $1.29 * * *$ & $1.24 * * *$ & $1.35^{* * *}$ & $1.26 * * *$ \\
\hline & $(0.00)$ & $(0.01)$ & $(0.01)$ & $(0.02)$ & $(0.02)$ & $(0.02)$ & $(0.02)$ \\
\hline \multirow[t]{2}{*}{ Log real GDP (destination) } & $0.85^{* * *}$ & $0.98 * * *$ & $0.99 * * *$ & $0.88^{* * *}$ & $0.86^{* * *}$ & $0.89 * * *$ & $0.86^{* * *}$ \\
\hline & $(0.00)$ & $(0.01)$ & $(0.01)$ & $(0.02)$ & $(0.02)$ & $(0.02)$ & $(0.02)$ \\
\hline \multirow[t]{2}{*}{ Free trade agreement } & $1.22^{* * *}$ & 0.36 *** & $0.34^{* * *}$ & $0.19^{* * *}$ & $0.20 * * *$ & $0.21 * * *$ & $0.20 * * *$ \\
\hline & $(0.02)$ & $(0.03)$ & $(0.02)$ & $(0.04)$ & $(0.04)$ & $(0.04)$ & $(0.04)$ \\
\hline \multirow[t]{2}{*}{ Log distance } & $-1.22 * * *$ & & & & & & \\
\hline & $(0.00)$ & & & & & & \\
\hline \multirow[t]{2}{*}{ Common language (dummy) } & $0.60 * * *$ & & & & & & \\
\hline & $(0.01)$ & & & & & & \\
\hline \multirow[t]{2}{*}{ Common border (dummy) } & $0.61^{* * *}$ & & & & & & \\
\hline & $(0.02)$ & & & & & & \\
\hline \multirow[t]{2}{*}{ Landlocked } & $-0.29 * * *$ & & & & & & \\
\hline & $(0.01)$ & & & & & & \\
\hline \multirow[t]{2}{*}{ Island } & $0.29 * * *$ & & & & & & \\
\hline & $(0.01)$ & & & & & & \\
\hline \multirow[t]{2}{*}{ Current colony } & $1.37^{* * *}$ & & & & & & \\
\hline & $(0.10)$ & & & & & & \\
\hline \multirow[t]{2}{*}{ Ever colony } & $1.28 * * *$ & & & & & & \\
\hline & $(0.02)$ & & & & & & \\
\hline \multirow[t]{2}{*}{ Log oil export share (Oil) } & & & $-0.04 * * *$ & $-0.03^{* * *}$ & $-0.03^{* * *}$ & $-0.03^{* * *}$ & $-0.03^{* * *}$ \\
\hline & & & $(0.00)$ & $(0.00)$ & $(0.00)$ & $(0.00)$ & $(0.00)$ \\
\hline \multirow[t]{2}{*}{ Corruption (Corr) } & & & & $0.50 * * *$ & & & \\
\hline & & & & $(0.03)$ & & & \\
\hline \multirow[t]{2}{*}{ Corr * Oil } & & & & $0.01^{* * *}$ & & & \\
\hline & & & & $(0.00)$ & & & \\
\hline \multirow[t]{2}{*}{ Bureaucratic quality (Burq) } & & & & & $0.59^{* * *}$ & & \\
\hline & & & & & $(0.03)$ & & \\
\hline \multirow[t]{2}{*}{ Burq * Oil } & & & & & $0.01^{* * *}$ & & \\
\hline & & & & & $(0.00)$ & & \\
\hline \multirow[t]{2}{*}{ Government stability (Stab) } & & & & & & $0.28 * * *$ & \\
\hline & & & & & & $(0.02)$ & \\
\hline \multirow[t]{2}{*}{ Stab * Oil } & & & & & & 0.00 & \\
\hline & & & & & & $(0.00)$ & \\
\hline \multirow[t]{2}{*}{ Institutional quality (Inst) } & & & & & & & $0.09 * * *$ \\
\hline & & & & & & & $(0.01)$ \\
\hline \multirow[t]{2}{*}{ Inst * Oil } & & & & & & & $0.01^{* * *}$ \\
\hline & & & & & & & $(0.00)$ \\
\hline \multirow[t]{2}{*}{ Log of infrastructure } & & & & $0.12 * * *$ & $0.10^{* * *}$ & $0.16^{* * *}$ & $0.12^{* * *}$ \\
\hline & & & & $(0.01)$ & $(0.01)$ & $(0.01)$ & $(0.01)$ \\
\hline Observations & 338,056 & 338,056 & 335,394 & 195,805 & 195,534 & 195,805 & 195,528 \\
\hline R-squared (within) & & 0.18 & 0.19 & 0.16 & 0.16 & 0.16 & 0.16 \\
\hline R-squared (between) & & 0.61 & 0.60 & 0.58 & 0.58 & 0.58 & 0.58 \\
\hline R-squared (overall) & 0.64 & 0.52 & 0.53 & 0.51 & 0.51 & 0.51 & 0.51 \\
\hline Hausman test ( $p$-value) & & 0.00 & 0.00 & 0.00 & 0.00 & 0.00 & 0.00 \\
\hline
\end{tabular}


Table 7. Institutions and Real Non-oil Exports: Estimates for Sub-Saharan Africa

\begin{tabular}{|c|c|c|c|c|c|c|c|}
\hline Estimation & $\frac{\text { Pooled-OLS }}{(1)}$ & $\frac{\text { Fixed Effects }}{(2)}$ & $\frac{\text { Fixed Effects }}{(3)}$ & $\frac{\text { Fixed Effects }}{(4)}$ & $\frac{\text { Fixed Effects }}{(5)}$ & $\frac{\text { Fixed Effects }}{(6)}$ & $\begin{array}{c}\text { Fixed Effects } \\
(7)\end{array}$ \\
\hline Log real GDP (origin) & $\begin{array}{l}0.98^{* * *} \\
(0.01)\end{array}$ & $\begin{array}{l}1.16^{* * *} \\
(0.05)\end{array}$ & $\begin{array}{l}1.22 \text { *** } \\
(0.06)\end{array}$ & $\begin{array}{l}1.56 \text { *** } \\
(0.09)\end{array}$ & $\begin{array}{l}1.40^{* * *} \\
(0.09)\end{array}$ & $\begin{array}{l}1.43^{\star * *} \\
(0.09)\end{array}$ & $\begin{array}{l}1.40 \text { *** } \\
(0.09)\end{array}$ \\
\hline Log real GDP (destination) & $\begin{array}{l}0.77^{* * *} \\
(0.01)\end{array}$ & $\begin{array}{l}0.69^{* * *} \\
(0.05)\end{array}$ & $\begin{array}{l}0.75^{\text {*** }} \\
(0.06)\end{array}$ & $\begin{array}{l}0.83^{\text {*** }} \\
(0.08)\end{array}$ & $\begin{array}{l}0.74^{* * *} \\
(0.08)\end{array}$ & $\begin{array}{l}0.76^{\text {*** }} \\
(0.08)\end{array}$ & $\begin{array}{l}0.72^{* * *} \\
(0.08)\end{array}$ \\
\hline Free trade agreement (dummy) & $\begin{array}{l}1.43^{* * *} \\
(0.05)\end{array}$ & $\begin{array}{l}0.83^{* * *} \\
(0.09)\end{array}$ & $\begin{array}{l}0.78 \text { *** } \\
(0.10)\end{array}$ & $\begin{array}{r}0.04 \\
(0.16)\end{array}$ & $\begin{array}{r}0.12 \\
(0.16)\end{array}$ & $\begin{array}{r}0.11 \\
(0.16)\end{array}$ & $\begin{array}{r}0.08 \\
(0.16)\end{array}$ \\
\hline Log distance & $\begin{array}{l}-0.80^{* * *} \\
(0.03)\end{array}$ & & & & & & \\
\hline Common language (dummy) & $\begin{array}{l}0.48^{* * *} \\
(0.03)\end{array}$ & & & & & & \\
\hline Common border (dummy) & $\begin{array}{l}1.511^{* * *} \\
(0.07)\end{array}$ & & & & & & \\
\hline Landlocked & $\begin{array}{l}-0.15^{* * *} \\
(0.02)\end{array}$ & & & & & & \\
\hline Island & $\begin{array}{l}0.08^{* * *} \\
(0.03)\end{array}$ & & & & & & \\
\hline Current colony & $\begin{array}{l}-1.50 * * * \\
(0.62)\end{array}$ & & & & & & \\
\hline Ever colony & $\begin{array}{l}2.79 \text { *** } \\
(0.07)\end{array}$ & & & & & & \\
\hline Log oil export share (Oil) & & & $\begin{array}{l}-0.022^{* * *} \\
(0.00)\end{array}$ & $\begin{array}{l}-0.08^{* * *} \\
(0.01)\end{array}$ & $\begin{array}{l}-0.03^{* * *} \\
(0.01)\end{array}$ & $\begin{array}{l}-0.02 \text { *** } \\
(0.01)\end{array}$ & $\begin{array}{l}-0.011^{* * *} \\
(0.00)\end{array}$ \\
\hline Corruption (Corr) & & & & $\begin{array}{r}1.88 \\
(0.18)\end{array}$ & & & \\
\hline Corr * Oil & & & & $\begin{array}{l}0.14^{* * *} \\
(0.01)\end{array}$ & & & \\
\hline Bureaucratic quality (Burq) & & & & & $\begin{array}{l}0.31^{* * *} \\
(0.10)\end{array}$ & & \\
\hline Burq * Oil & & & & & $\begin{array}{l}0.02 \text { *** } \\
(0.01)\end{array}$ & & \\
\hline Government stability (Stab) & & & & & & $\begin{array}{r}0.03 \\
(0.11)\end{array}$ & \\
\hline Stab * Oil & & & & & & $\begin{array}{l}0.02 \\
(0.01)\end{array}$ & \\
\hline Institutional quality (Inst) & & & & & & & $\begin{array}{l}0.28^{* * *} \\
(0.03)^{*}\end{array}$ \\
\hline Inst * Oil & & & & & & & $\begin{array}{l}0.02 \text { *** } \\
(0.00)\end{array}$ \\
\hline Log of infrastructure & & & & $\begin{array}{l}0.43^{* * *} \\
(0.04)\end{array}$ & $\begin{array}{l}0.39 \text { *** } \\
(0.04)\end{array}$ & $\begin{array}{l}0.39 \text { *** } \\
(0.03)\end{array}$ & $\begin{array}{l}0.40^{\text {*** }} \\
(0.04)\end{array}$ \\
\hline Observations & 39,499 & 39,499 & 37,306 & 24,487 & 24,487 & 24,487 & 24,487 \\
\hline R-squared (within) & & 0.05 & 0.05 & 0.05 & 0.05 & 0.05 & 0.05 \\
\hline R-squared (between) & & 0.33 & 0.33 & 0.30 & 0.30 & 0.30 & 0.30 \\
\hline R-squared (overall) & 0.37 & 0.25 & 0.25 & 0.24 & 0.24 & 0.24 & 0.24 \\
\hline Hausman test ( $p$-value) & & 0.00 & 0.00 & 0.00 & 0.00 & 0.00 & 0.00 \\
\hline
\end{tabular}

Notes: Dependent variable is (log of) real non-oil exports; constant and year dummies included in all specifications; robust standard errors reported in parentheses; ${ }^{*},{ }^{* *},{ }^{* *}$ denote significance at the 10,5 and 1 percent levels, respectively; institutional quality refers to the first principal component of the corruption, bureaucratic quality and govt. stability indices. 
Table 8. Estimates for Countries with Low and High Institutional Quality

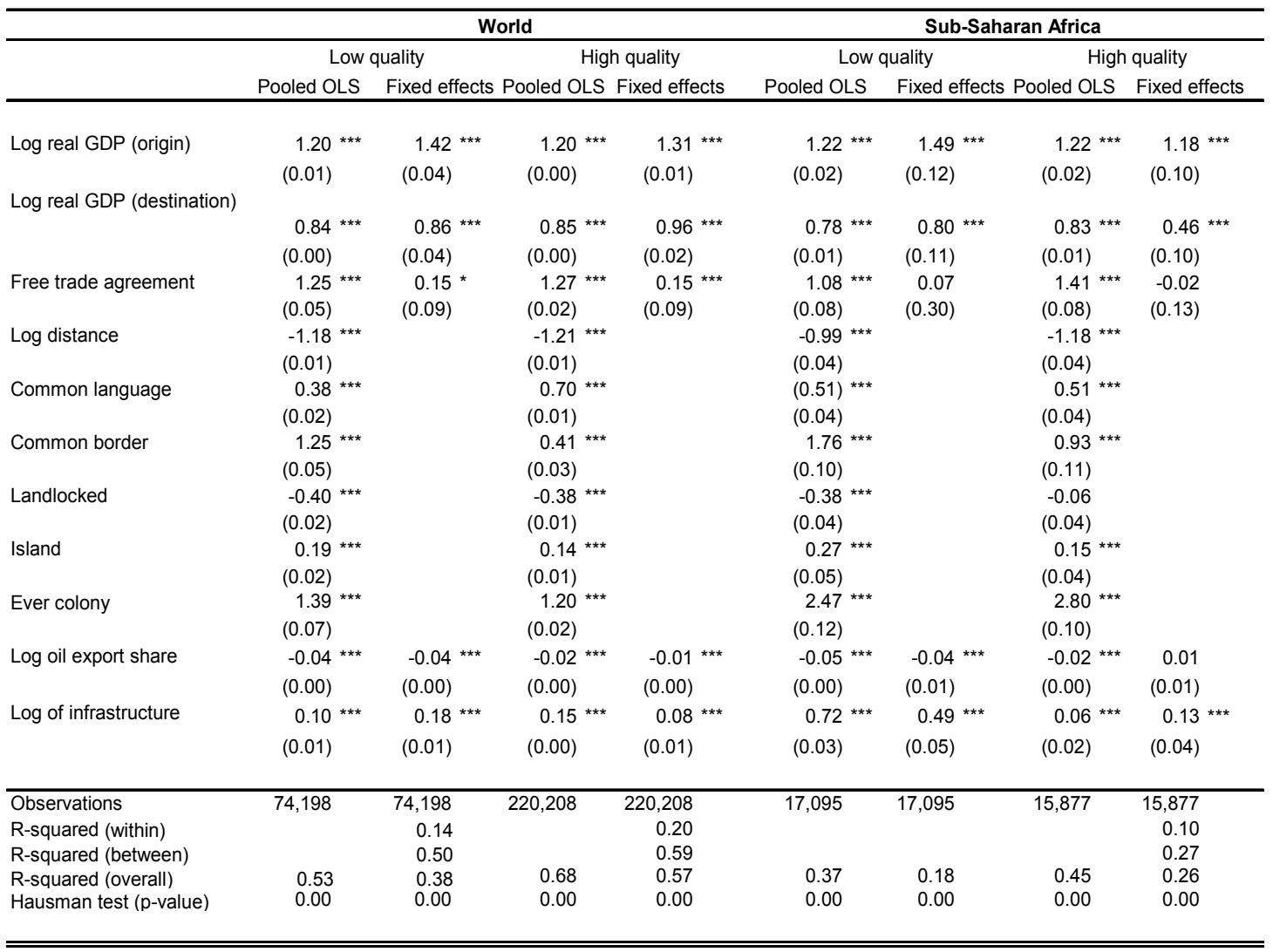

Notes: Dependent variable is (log of) real non-oil exports; low (high) institutional quality defined as below (above or equal to) median score of the first principal component of corruption, bureaucratic quality, and government stability indices; constant and year dummies included in all estimations; robust standard errors reported in parentheses; ${ }^{*},{ }^{* \star},{ }^{\star \star \star}$ denote significance at the 10,5 and 1 percent levels, respectively.

\section{Conclusion ANd Policy Implications}

This paper compares the competitiveness of oil-rich African countries and other oil-exporting developing countries using a comprehensive set of structural indicators. The analysis reveals that most OPAC have a highly concentrated economic base and rely heavily on oil exports for earning foreign exchange. The performance of their non-fuel merchandise sector has been dismal, and their share in world exports has declined steadily. Except for Côte d'Ivoire, none of the OPAC have been able to acquire a comparative advantage in additional product categories over the years, and some like Angola and Congo have lost their comparative advantage in a number of sectors.

The experience of OPAC, particularly Angola, Gabon, Congo, and Nigeria, is in contrast to that of Indonesia, Trinidad and Tobago, and the UAE, which successfully diversified their economic bases despite the oil booms in the 1970s and 1980s. The performance of the UAE in this regard is striking; it has a manufacturing base today despite having virtually none in the 1970s. Looking at other factors that enhance competitiveness, it is apparent that the UAE stands out in terms of infrastructure, human capital development, and the quality of institutions and governance. Interestingly, Venezuela, which performs relatively poorly among the comparator oil-exporting countries in terms of diversification and non-oil export 
performance, also has a relatively poor weak standard of physical and human infrastructure, governance, and institutional capacity. These observations support the view that institutional factors can enhance diversification and improve the performance of the non-oil sector. The fact that the OPAC have not emphasized these factors sufficiently may have curtailed the development of their tradable sector.

The gravity model of trade confirms these observations and we find that infrastructure and institutions, especially bureaucratic quality and corruption control, are highly significant in determining real non-oil export flow. More importantly, the results show that although oil abundance has a strongly negative effect on the export competitiveness of the non-oil tradable sector, institutional quality is a significant determinant of the extent to which this negative effect sets in. This implies that oil abundance does not necessarily weaken the tradable sector; countries may benefit from oil booms if the revenues are used to create an environment that promotes the non-oil tradables sector. This finding is robust to the choice of oil abundance and institutional quality variables, model specification and the inclusion of zero observations in the data set.

Interestingly, the effects of institutions and infrastructure are larger for oil rich African economies. These countries stand to benefit substantially from oil abundance if revenues are managed prudently to remove supply-side constraints and create an environment that makes the tradable sector more dynamic. This result has important policy implications particularly in the current global environment where Asia's continued growth has stimulated oil demand and pushed up prices. The recent oil boom and subsequent windfall oil revenues, and the economic growth momentum offer the OPAC a unique opportunity to undo their economic and institutional shortcomings, rebuild their economies on a solid foundation, and diversify, to escape the problems traditionally associated with resource booms. This is particularly important for oil exporters with declining oil reserves, given the urgency to prepare for the post-oil era. The OPAC producers may also find opportunities for diversification as labor costs rise in East Asia and the demand pattern changes with middle class growth in emerging economies. Diversification would not only reduce exposure to external shocks and enhance international competitiveness; it may also lead to a more even distribution of the gains from oil revenue, increase productivity, and ensure sustainable long-run growth. In this regard, the OPAC countries have much to learn from other oil-exporting nations that improved their investment climate and diversified successfully to protect themselves from exogenous shocks and economic uncertainty. 


\section{REFERENCES}

Abdih, Y., and C. Tsangarides, 2008, "FEER for the CFA Franc," Applied Economics (forthcoming).

Anderson, J., 1979, “A Theoretical Foundation for the Gravity Equation,” American Economic Review, Vol. 69, pp. 106-16.

and D. Marcouiller, 2002, "Insecurity and the Pattern of Trade: An Empirical Investigation," Review of Economics and Statistics, Vol. 84(2), pp. 342-52.

, and E. van Wincoop, 2001, "Gravity with Gravitas: A Solution to the Border Puzzle,” NBER Working Paper No. 8079 (Cambridge, MA: National Bureau of Economic Research).

Auty, R.M., 1990, Resource-Based Industrialization: Sowing the Oil in Eight Developing Countries (New York: Oxford University Press).

Baldwin, R., 2006, “The Euro's Trade Effects,” ECB Working Paper. 594 (Frankfurt: European Central Bank).

Bergstrand, J., 1985, "The Gravity Equation in International Trade: Some Microeconomic Foundations and Empirical Evidence," Review of Economics and Statistics, Vol. 67, pp. 474-81.

, 1989, "The Generalized Gravity Equation Monopolistic Competition, and the Factor-Proportions Theory in International Trade," Review of Economics and Statistics, Vol. 71, pp. 143-53.

Biggs, T., M. Shah, and P. Srivastava, 1995, "Technological Capabilities and Learning in African Enterprises," World Bank Technical Paper No. 288 (Washington: World Bank).

, and P. Srivastava, 1996, "Structural Aspects of Manufacturing in Sub-Saharan Africa," World Bank Discussion Paper No. 345 (Washington: World Bank).

Bigsten, A., A. Isaksson, M. Soderbom, P. Collier, A. Zeufack, S. Dercon, M. Fafchamps, J. W. Gunning, F. Teal, S. Appleton, B. Gauthier, A. Oduro, R. Oostendorp, and C. Pattillo, 2000, "Rates of Return on Physical and Human Capital in Africa's Manufacturing Sector," Economic Development and Cultural Change, Vol. 48, No. 4, pp. 801-27.

Carey, K., S. Gupta, and U. Jacoby, 2007, Sub-Saharan Africa: Forging New Trade Links with Asia (Washington: International Monetary Fund).

Cerra, V., and S.C. Saxena, 2002, "What Caused the 1991 Crisis in India?" IMF Staff Papers, Vol. 49, No. 3, pp. 395-425. 
Chudik, A., and J. Mongardini, 2006, "In Search of Equilibrium: Estimating Equilibrium Real Exchange Rates in Low-Income African Countries," IMF Working Paper No. 07/90 (Washington: International Monetary Fund).

Ciuriak, Dan, and Shinji Kinjo, 2006, "Trade Specialization in the Gravity Model of International Trade,", in Trade Policy Research 2005, ed. by John M. Curtis and Dan Ciuriak (Ottawa: Foreign Affairs and International Trade Canada).

Collier, P., 1994, "Devaluation: The Experience of Anglophone Africa", Dialogure No. 2, (Paris: Développement Institutions et Analyses de Long Terme).

, 1997, "Globalization: Implications for Africa," in Trade Reform and Regional Integration in Africa, ed. by Z. Iqbal and M. Khan (Washington: International Monetary Fund).

, and Jan Willem Gunning, 1999, "Explaining Africa's Economic Performance," Journal of Economic Literature, Vol. 37, No. 1, pp. 64-111. , and A. Hoffler, 2004, "Greed and Grievance in African Civil Wars," Oxford Economic Papers, Vol. 56. No. 4, pp. 563-95.

Deardorff, A. V., 1982, "The General Validity of the Heckscher-Ohlin Theorem," American Economic Review, Vol. 72, No. 4, pp. 683-94.

Di Bella, G., M. Lewis, and A. Martin, 2007, “Assessing Competitiveness and Real Exchange Rate Misalignments in Low-Income Countries," IMF Working Paper No. 07/201 (Washington: International Monetary Fund).

Dufrenot, G., and E. B. Yehoue, 2005, "Real Exchange Rate Misalignment: A Panel CoIntegration and Common Factor Analysis," IMF Working Paper No. 05/164 (Washington: International Monetary Fund).

Feenstra, R., J. Markusen, and A. Rose, 2001, "Using the Gravity Model to Differentiate Among Alternative Theories of Trade," Canadian Journal of Economics, Vol. 34, No. 2, pp. 430-47.

Francois, J., and M. Manchin, 2007, “Institutions, Infrastructure and Trade," CEPR Discussion Paper No. 6068 (London: Centre for Economic Policy Research).

Fukunishi, Takahiro, 2004, "International Competitiveness of Manufacturing Firms in SubSaharan Africa: Why Has the Manufacturing Sector Remained Small?" IDE Discussion Paper No. 2 (Chiba: Institute of Developing Economies).

Ghura, D., and T. Grennes, 1993, "The Real Exchange Rate and Macroeconomic Performance in Sub-Saharan Africa," Journal of Development Economics, Vol. 42, pp. $155-74$. 
Gupta, Sanjeev, and Yongzheng Yang, 2006, "What Impedes Africa's Trade?" Finance and Development, Vol. 43, No. 4, pp. 22-25.

Heston, A., R. Summers, and B. Aten, 2006, Penn World Table Version 6.2 (Philadelphia: Center for International Comparisons of Production, Income and Prices, University of Pennsylvania).

Hilaire, N., and J. Doucet, 2004, "Dutch Disease, Oil and Developing Countries," unpublished manuscript (Canada: University of Alberta).

Iimi, A., 2007, "Escaping from the Resource Curse: Evidence from Botswana and the Rest of the World," IMF Staff Papers, Vol. 54, No. 4, pp. 663-700.

International Monetary Fund, 2002, World Economic Outlook,September 2007 (Washington: IMF). ,2007, Regional Economic Outlook: Sub-Saharan Africa, April 2007 (Washington: IMF).

Krugman, P., 1987, “The Narrow Moving Band, the Dutch Disease, and the Competitive Consequences of Mrs. Thatcher on Trade in the Presence of Dynamic Scale Economies," Journal of Development Economics, Vol. 27, pp. 41-55.

Leite, C., and J. Weidmann, 1999, "Does Mother Nature Corrupt? Natural Resources, Corruption, and Economic Growth," IMF Working Paper No. WP/99/85 (Washington: International Monetary Fund).

Mainardi, S., 1995, "Mineral Resources and Growth: Toward a Long-term Convergence?" Resources Policy, Vol. 21, No. 3, pp. 155-68.

Mehlum, H., K. Moene, and R. Torvik, 2006, "Institutions and the Resource Curse," Economic Journal, Vol. 116, No. 508, pp. 1-20.

Murgasova, Z., 2004, “Assessing Competitiveness," in Republic of Poland: Selected Issues, IMF Country Report No. 04/197 (Washington: International Monetary Fund).

Neary, J. P., and S. Van Wijnbergen, 1986, Natural Resources and the Macroeconomy (Oxford: Basil Blackwell).

Pack, H., 1987, Productivity, Technology and Industrial Development: A Case-Study in Textiles (New York: Oxford University Press).

Ramirez, G., and C. Tsangarides, 2007, "Competitiveness in the CFA Franc Zone," IMF Working Paper No. 07/212 (Washington: International Monetary Fund). 
Rose, A., 2002, "Estimating Protectionism through Residuals from the Gravity Model," Background Chapter for the WEO, Spring 2007 (Berkeley: University of California).

Sachs, J., and A. Warner, 1995, "Natural Resource Abundance and Economic Growth," NBER Working Paper No. 5398 (Cambridge, MA: National Bureau of Economic Research).

Sala-i-Martin, X., and A. Subramanian, 2003, "Addressing the Natural Resource Curse: An Illustration from Nigeria," IMF Working Paper No. WP/03/139 (Washington: International Monetary Fund).

Santos Silva, J., and S. Tenreyra, 2006, "The Log of Gravity," The Review of Economics and Statistics, Vol. 88, No. 4, pp. 641-58.

Sekkat, K., and A. Varoudakis, 2000, "Exchange Rate Management and Manufactured Exports in Sub-Saharan Africa," Journal of Development Economics, Vol. 61, No. 1, pp. 237-53.

Söderling, Ludvig, 2000, "Dynamics of Export Performance, Productivity, and Real Effective Exchange Rate in Manufacturing: the Case of Cameroon," Journal of African Economies, Vol. 9, No. 4, pp. 411-29.

Stijns, J., 2003, “An Empirical Test of the Dutch Disease Hypothesis Using a Gravity Model of Trade" (unpublished; Berkeley: University of California).

Tajoli, Lucia, and Lucia De Benedictis, 2006, "Economic Integration and Similarity in Trade Structures,” FEEM Working Paper No. 2006-54 (Italy: Fondazione Eni Enrico Mattei).

Tinbergen, J., 1962, Shaping the World Economy: Suggestions for an International Trade Policy (New York: Twentieth Century Fund).

Tsangarides, C., P. Ewenczyk, and M. Hulej, 2006, "Stylized Facts on Bilateral Trade and Currency Unions,” IMF Working Paper No. WP/06/31 (Washington: International Monetary Fund).

Tybout, James R., 2000, "Manufacturing Firms in Developing Countries: How Well Do They Do, and Why?" Journal of Economic Literature, Vol. 38, No. 1, pp. 11-44.

UNCTAD, 2003, Economic Development in Africa: Trade Performance and Commodity Dependence (Geneva: United Nations Conference on Trade and Development).

UNECA, 2007, Economic Report on Africa 2007: Accelerating Africa's Development Through Diversification (Addis Ababa: United Nations Economic Commission on Africa). 
Usui, N., 1997, "Dutch Disease and Policy Adjustments to the Oil Boom: A Comparative Study of Indonesia and Mexico," Resources Policy, Vol. 23, No. 4, pp. 151-62.

van Wijnbergen, Sweder, 1984, "Inflation, Employment, and the Dutch Disease in OilExporting Countries: A Short-Run Disequilibrium Analysis," Quarterly Journal of Economics, Vol. 99, No. 2, pp. 233-50.

World Bank, 2004, Patterns of Africa-Asia Trade and Investment: Potential for Ownership and Partnership, Africa Region, Private Sector Unit (Washington: World Bank).

WEF, 2007, African Competitiveness Report 2007, (Geneva: World Economic Forum). 


\section{APPENDIX A: MACROECONOMIC INDICATORS AND EXPORT PERFoRMANCE}

Table A1. Real GDP and GDP Per Capita Growth Rates for OPAC, 1980-2006 (percent) 1/

\begin{tabular}{|c|c|c|c|c|c|}
\hline & $1980-84$ & $1985-89$ & $1990-94$ & 1995-99 & 2000-06 \\
\hline \multicolumn{6}{|l|}{ Real GDP Growth } \\
\hline Angola & 1.64 & 3.33 & -6.19 & 8.75 & 10.62 \\
\hline Cameroon & 9.77 & 0.62 & -3.73 & 4.57 & 3.74 \\
\hline Chad & 1.90 & 5.40 & 3.88 & 2.65 & 10.86 \\
\hline Congo, Republic of & 4.49 & 10.04 & -0.09 & 1.76 & 4.87 \\
\hline Côte d'Ivoire & 0.88 & 2.40 & 2.02 & 5.62 & -0.51 \\
\hline Equatorial Guinea & 3.77 & 3.29 & 19.03 & 47.79 & 19.87 \\
\hline Gabon & 1.40 & 1.45 & 3.17 & 1.78 & 1.10 \\
\hline Nigeria & -1.05 & 4.51 & 2.82 & 2.79 & 5.65 \\
\hline OPAC & 2.85 & 3.88 & 2.61 & 9.46 & 7.03 \\
\hline Non-oil resource intensive Africa & 2.02 & 5.93 & 3.48 & 7.35 & 5.02 \\
\hline Non-resource intensive Africa & 2.37 & 2.39 & 0.39 & 3.16 & 4.02 \\
\hline \multicolumn{6}{|l|}{ Real Non-oil GDP Growth } \\
\hline Angola & -28.63 & 9.44 & -16.19 & 10.19 & 10.85 \\
\hline Cameroon & $\ldots$ & $\ldots$ & $\ldots$ & $\ldots$ & 4.46 \\
\hline Chad & 8.76 & 5.40 & 3.88 & 2.62 & 5.58 \\
\hline Congo, Republic of & -9.25 & 10.31 & -1.73 & -2.69 & 8.28 \\
\hline Côte d'Ivoire & $\ldots$ & $\ldots$ & 0.17 & 5.10 & -0.82 \\
\hline Equatorial Guinea & 3.77 & 3.29 & 3.64 & 13.98 & 27.72 \\
\hline Gabon & $\ldots$ & $\ldots$ & 1.43 & 3.21 & 2.79 \\
\hline Nigeria & -13.40 & 5.32 & 2.76 & 3.28 & 6.42 \\
\hline OPAC & -7.75 & 6.75 & -0.86 & 5.10 & 8.16 \\
\hline Non-oil resource intensive Africa & $\ldots$ & $\ldots$ & 1.82 & 7.06 & 4.88 \\
\hline Non-resource intensive Africa & $\ldots$ & $\ldots$ & 2.53 & 3.16 & 4.04 \\
\hline \multicolumn{6}{|l|}{ Real Per Capita GDP Growth } \\
\hline Angola & -1.17 & -1.18 & -8.72 & 5.55 & 7.47 \\
\hline Cameroon & 6.75 & -2.16 & -6.57 & 1.72 & 0.72 \\
\hline Chad & 1.34 & 2.83 & 1.43 & -0.55 & 7.13 \\
\hline Congo, Republic of & -0.62 & 6.04 & -3.05 & -0.53 & 1.92 \\
\hline Côte d'Ivoire & -5.14 & -0.90 & -2.73 & 2.84 & -2.20 \\
\hline Equatorial Guinea & -4.24 & -3.60 & 11.09 & 36.97 & 14.72 \\
\hline Gabon & -0.44 & -0.74 & 0.47 & -0.71 & -1.36 \\
\hline Nigeria & -5.17 & 1.49 & -0.10 & -0.12 & 2.90 \\
\hline OPAC & -1.09 & 0.22 & -1.02 & 5.65 & 3.91 \\
\hline Non-oil resource intensive Africa & -2.34 & 1.01 & -2.51 & 3.02 & 2.24 \\
\hline Non-resource intensive Africa & $\ldots$ & $\ldots$ & -2.11 & 1.03 & 2.25 \\
\hline
\end{tabular}

$1 / \ldots$ indicates data not available

Source: IMF, African Department database. 
Table A2. Macroeconomic indicators for selected oil exporting countries, 1970-2006 1/

\begin{tabular}{|c|c|c|c|c|c|c|c|c|c|c|c|c|c|}
\hline & AGO & CMR & TCD & COG & CIV & GNQ & GAB & NGA & IDN & MEX & TTO & ARE & VEN \\
\hline \multicolumn{14}{|c|}{ Real GDP growth } \\
\hline $1970-79$ & $\ldots$ & 7.3 & -1.0 & 5.5 & 7.6 & $\ldots$ & 9.9 & 7.0 & 7.8 & 6.4 & 4.6 & 12.6 & 4.0 \\
\hline 1980-89 & 2.7 & 4 & 5.4 & 6.8 & -0.2 & 0.9 & 1.9 & 0.9 & 6.4 & 2.3 & -1.3 & 1.2 & -0.2 \\
\hline $1990-99$ & 1.0 & 0.41 & 2.2 & 0.8 & 2.6 & 20.2 & 2.5 & 3.1 & 4.8 & 3.4 & 2.7 & 5.6 & 2.5 \\
\hline $2000-06$ & 10.4 & 3.8 & 11.1 & 5.1 & -0.2 & 20.0 & 1.1 & 5.6 & 4.9 & 2.9 & 8.4 & 7.6 & 4.2 \\
\hline \multicolumn{14}{|c|}{ Oil export of total export (\%) } \\
\hline $1970-79$ & 47.59 & $\ldots$ & 0.05 & 23.10 & $\ldots$ & 0.40 & 34.16 & 74.25 & 66.20 & 4.41 & 66.04 & 12.08 & 86.10 \\
\hline $1980-89$ & 78.08 & 28.41 & 0.00 & 55.61 & 12.86 & 0.00 & 59.95 & 92.91 & 53.49 & 39.23 & 62.85 & 67.12 & 81.27 \\
\hline 1990-99 & 88.88 & 32.70 & 0.00 & 81.41 & 10.99 & 47.97 & 70.92 & 90.05 & 14.30 & 11.75 & 39.48 & 51.47 & 70.40 \\
\hline $2000-06$ & 88.36 & 34.57 & 40.00 & 82.42 & 17.71 & 96.02 & 77.83 & 85.50 & 10.18 & 10.85 & 57.58 & 45.13 & 80.93 \\
\hline \multicolumn{14}{|c|}{ Oil export of world oil export (\%) } \\
\hline $1970-79$ & 1.14 & 0 & 0 & 0.06 & 0 & 0 & 0.49 & 6.26 & 4.32 & 0.29 & 0.92 & 0.71 & 8.43 \\
\hline 1980-89 & 0.77 & 0.32 & 0 & 0.25 & 0.22 & 0 & 0.55 & 4.49 & 4.19 & 4.7 & 0.58 & 4.61 & 5.05 \\
\hline $1990-99$ & 1.25 & 0.26 & 0 & 0.39 & 0.15 & 0.05 & 0.68 & 4.06 & 2.18 & 3.14 & 0.35 & 5.49 & 4.79 \\
\hline $2000-06$ & 1.59 & 0.16 & 0.1 & 0.39 & 0.15 & 0.46 & 0.43 & 3.91 & 1.16 & 2.92 & 0.54 & 4.89 & 4.34 \\
\hline \multicolumn{14}{|c|}{ Agriculture, value added ( $\%$ of GDP) } \\
\hline $1970-79$ & $\ldots$ & 30.7 & 38.3 & 15.6 & 27.8 & $\ldots$ & 9.6 & 33.6 & 34.02 & 11.6 & $\ldots$ & 0.85 & 5.15 \\
\hline 1980-89 & 15.2 & 25.7 & 36.9 & 10 & 27.1 & 65.8 & 7.7 & 33.4 & 23.18 & 8.97 & 2.86 & 1.38 & 5.87 \\
\hline $1990-99$ & 11.3 & 24.3 & 36.7 & 10.55 & 27.3 & 41.5 & 7.8 & 31.1 & 17.91 & 6.2 & 2.38 & 2.74 & 5.23 \\
\hline $2000-06$ & 7.6 & 21.4 & 31.8 & 5.5 & 22.9 & 5.5 & 5.7 & 25.4 & 14.95 & 3.97 & 1.2 & 3.08 & 4.35 \\
\hline \multicolumn{14}{|c|}{ Manufacturing, value added (\% of GDP) } \\
\hline $1970-79$ & $\ldots$ & 9.7 & 11.6 & 8.9 & 9.4 & $\ldots$ & 5.6 & 4.8 & 10.4 & 22.7 & $\ldots$ & 2.3 & 16.1 \\
\hline $1980-89$ & 8.5 & 12.1 & 11.8 & 6.8 & 15.7 & $\ldots$ & 6.2 & 8.2 & 15.4 & 23.1 & 10.5 & 8.2 & 17.4 \\
\hline $1990-99$ & 4.9 & 19.0 & 11.1 & 7.4 & 18.4 & 1.7 & 5.3 & 5.0 & 23.7 & 20.5 & 9.3 & 10.1 & 16.7 \\
\hline $2000-06$ & 3.6 & 19.9 & 7.3 & 5.2 & 17.3 & 6.1 & 4.4 & 4.0 & 29.0 & 18.6 & 7.3 & 13.6 & 18.4 \\
\hline \multicolumn{14}{|c|}{ Services, value added (\% of GDP) } \\
\hline $1970-79$ & $\ldots$ & 50.8 & 47.8 & 56.2 & 54.8 & $\ldots$ & 34.6 & 35.9 & 35.91 & 56.23 & $\ldots$ & 24.06 & 50.7 \\
\hline $1980-89$ & 45.4 & 42.5 & 49.6 & 44.9 & 52 & 25.2 & 38.6 & 38.7 & 38.7 & 57.03 & 54.9 & 34.89 & 45.9 \\
\hline $1990-99$ & 31.8 & 45.4 & 49.6 & 44.1 & 50.6 & 20 & 44.1 & 40.3 & 40.32 & 65.78 & 52.4 & 42.67 & 44.9 \\
\hline 2000-06 & 23.6 & 46.1 & 36.8 & 27.4 & 56 & 4.1 & 38.7 & 40.2 & 40.16 & 69.38 & 47.5 & 44.31 & 46.4 \\
\hline
\end{tabular}

Table A3. Share of Total and Non-Oil Exports in World Exports, 1970-2006 (percent)

\begin{tabular}{lcccccc}
\hline & & Total Exports & \multicolumn{3}{c}{ Non-oil Exports } \\
\hline & $\mathbf{1 9 7 0 - 8 9}$ & $\mathbf{1 9 9 0 - 9 9}$ & $\mathbf{2 0 0 0 - 0 6}$ & $\mathbf{1 9 7 0 - 8 9}$ & $\mathbf{1 9 9 0 - 9 9}$ & $\mathbf{2 0 0 0 - 0 6}$ \\
\hline OPAC & $\mathbf{1 . 0 9}$ & $\mathbf{0 . 4 4}$ & $\mathbf{0 . 6 8}$ & $\mathbf{0 . 2 9}$ & $\mathbf{0 . 1 0}$ & $\mathbf{0 . 1 1}$ \\
Angola & 0.13 & 0.07 & 0.13 & 0.06 & 0.01 & 0.01 \\
Cameroon & 0.08 & 0.04 & 0.03 & 0.05 & 0.02 & 0.01 \\
Chad & 0.01 & 0.00 & 0.01 & 0.00 & 0.00 & 0.00 \\
Congo, Republic of & 0.03 & 0.02 & 0.03 & 0.01 & 0.00 & 0.00 \\
Côte d'Ilvoire & 0.12 & 0.07 & 0.06 & 0.07 & 0.05 & 0.05 \\
Equatorial Guinea & 0.00 & 0.00 & 0.04 & 0.00 & 0.00 & 0.00 \\
Gabon & 0.11 & 0.05 & 0.04 & 0.03 & 0.01 & 0.01 \\
Nigeria & 0.61 & 0.23 & 0.34 & 0.07 & 0.01 & 0.03 \\
SSA & 2.76 & 1.52 & 1.60 & 1.55 & 0.90 & 0.79 \\
Indonesia & 0.67 & 0.82 & 0.80 & 0.23 & 0.61 & 0.64 \\
Mexico & 0.89 & 1.48 & 2.00 & 0.43 & 1.14 & 1.65 \\
Trinidad and Tobago & 0.10 & 0.04 & 0.07 & 0.02 & 0.02 & 0.02 \\
United Arab Emirates & 0.58 & 0.55 & 0.79 & 0.28 & 0.24 & 0.40 \\
Venezuela & 0.69 & 0.35 & 0.39 & 0.05 & 0.07 & 0.06 \\
\hline
\end{tabular}

Source: World Economic Outlook database. 


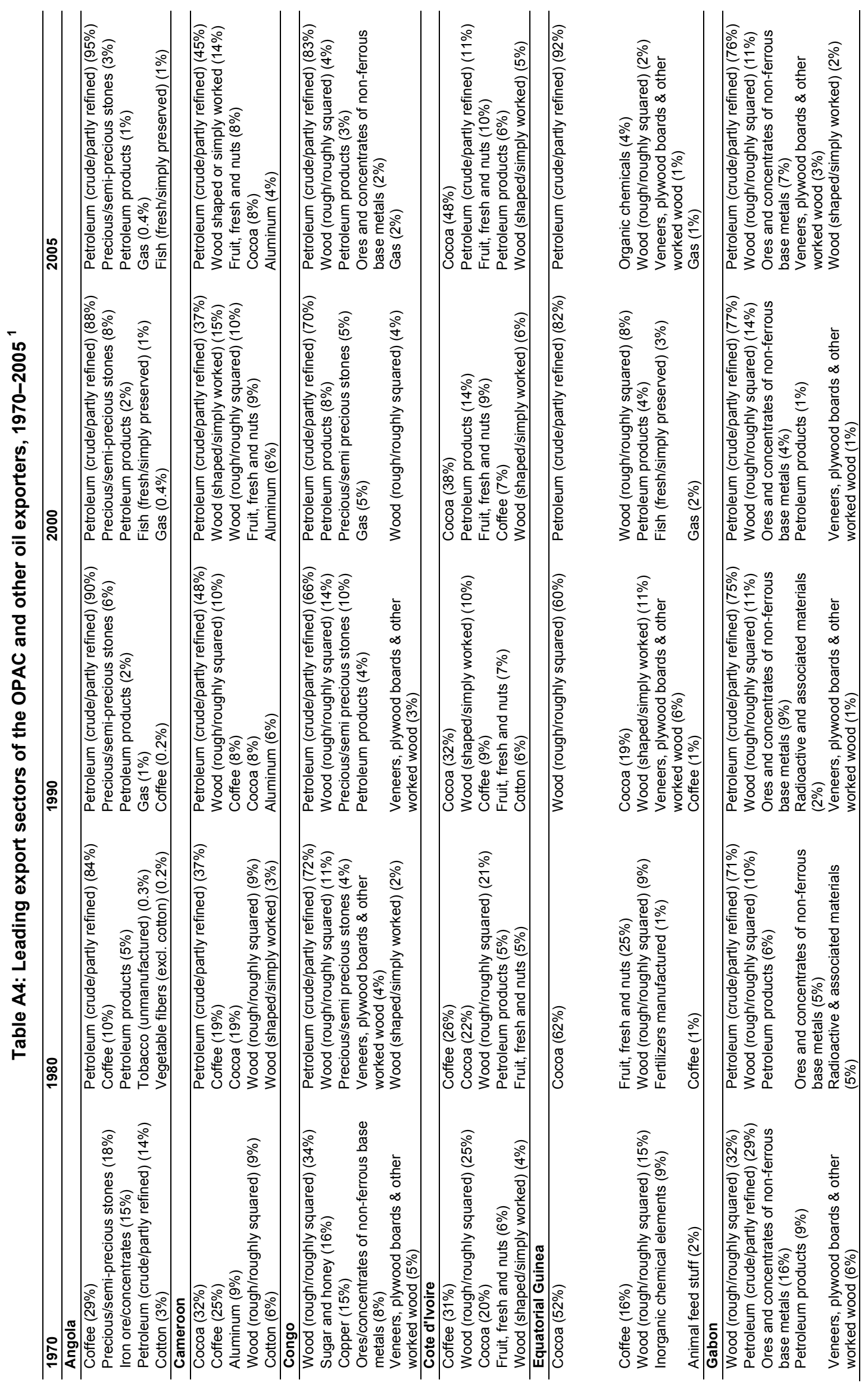




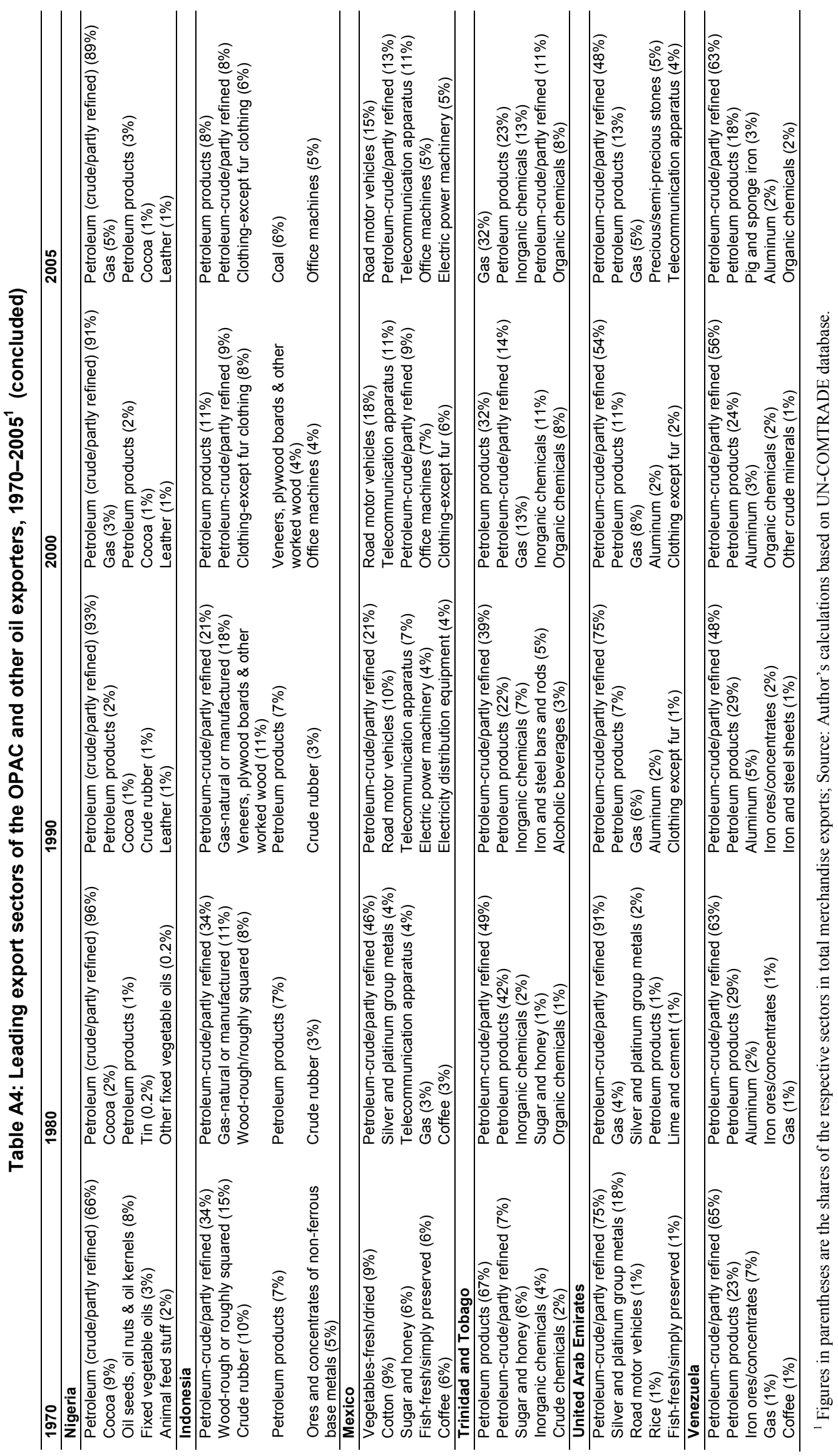


Table A5. Doing Business Indicators for Selected Economies, $2007^{1}$

\begin{tabular}{|c|c|c|c|c|c|c|c|c|c|c|c|c|c|c|}
\hline & AGO & CMR & TCD & COG & CIV & GNQ & GAB & NGA & SSA & IDN & MEX & TTO & UAE & VEN \\
\hline \multicolumn{15}{|l|}{$\begin{array}{l}\text { Ease of Doing } \\
\text { Business }\end{array}$} \\
\hline $\begin{array}{l}\text { Average rank (out of } \\
\text { 178) } \\
\text { Starting a Business }\end{array}$ & 167 & 154 & 173 & 175 & 155 & 165 & 144 & 108 & 136 & 123 & 44 & 67 & 68 & 172 \\
\hline Procedures (number) & 12 & 13 & 19 & 10 & 10 & 20 & 9 & 9 & 11 & 12 & 8 & 9 & 11 & 16 \\
\hline Time (days) & 119 & 37 & 75 & 37 & 40 & 136 & 58 & 34 & 56 & 105 & 27 & 43 & 62 & 141 \\
\hline $\begin{array}{l}\text { Cost (\% of income per } \\
\text { capita) }\end{array}$ & 344 & 129 & 189 & 150 & 136 & 105 & 164 & 57 & 148 & 80 & 13 & 1 & 37 & 28.2 \\
\hline Rank & 173 & 160 & 177 & 154 & 155 & 172 & 147 & 80 & 125 & 168 & 75 & 40 & 158 & 134 \\
\hline \multicolumn{15}{|l|}{$\begin{array}{l}\text { Dealing with } \\
\text { Licenses }\end{array}$} \\
\hline Procedures (number) & 14 & 15 & 9 & 14 & 21 & 18 & 14 & 18 & 18 & 19 & 11 & 20 & 21 & 11 \\
\hline Time (days) & 337 & 426 & 181 & 169 & 628 & 201 & 210 & 350 & 262 & 196 & 131 & 261 & 125 & 395 \\
\hline $\begin{array}{l}\text { Cost (\% of income per } \\
\text { capita) }\end{array}$ & 1110 & 1203 & 1064 & 566 & 248 & 240 & 48 & 1016 & 2549 & 287 & 104 & 6 & 2 & 326 \\
\hline $\begin{array}{l}\text { Rank } \\
\text { Employing Workers }\end{array}$ & 136 & 154 & 68 & 67 & 157 & 90 & 44 & 161 & 113 & 99 & 21 & 79 & 38 & 95 \\
\hline $\begin{array}{l}\text { Difficulty of Hiring } \\
\text { Index }\end{array}$ & 78 & 28 & 39 & 78 & 33 & 67 & 17 & 0 & 42 & 72 & 33 & 0 & 0 & 78 \\
\hline Rigidity of Hours Index & 60 & 40 & 60 & 60 & 60 & 60 & 80 & 0 & 44 & 0 & 40 & 0 & 60 & 60 \\
\hline $\begin{array}{l}\text { Difficulty of Firing } \\
\text { Index }\end{array}$ & 70 & 70 & 40 & 70 & 20 & 70 & 80 & 20 & 42 & 60 & 70 & 20 & 0 & 100 \\
\hline $\begin{array}{l}\text { Rigidity of } \\
\text { Employment Index }\end{array}$ & 69 & 46 & 46 & 69 & 38 & 66 & 59 & 7 & 43 & 44 & 48 & 7 & 20 & 79 \\
\hline $\begin{array}{l}\text { Nonwage labor cost } \\
\text { (\% of salary) }\end{array}$ & 8 & 16 & 21 & 29 & 18 & 23 & 20 & 9 & 12 & 10 & 21 & 3 & 13 & 16 \\
\hline $\begin{array}{l}\text { Firing costs (weeks of } \\
\text { wages) }\end{array}$ & 58 & 33 & 36 & 33 & 49 & 133 & 43 & 50 & 68 & 108 & 52 & 67 & 84 & NP \\
\hline $\begin{array}{l}\text { Rank } \\
\text { Registering Property }\end{array}$ & 172 & 120 & 135 & 167 & 112 & 175 & 163 & 30 & 116 & 153 & 134 & 38 & 65 & 177 \\
\hline Procedures (number) & 7 & 5 & 6 & 7 & 7 & 6 & 8 & 14 & 7 & 7 & 5 & 8 & 3 & 8 \\
\hline Time (days) & 334 & 93 & 44 & 137 & 62 & 23 & 60 & 82 & 105 & 42 & 74 & 162 & 6 & 47 \\
\hline $\begin{array}{l}\text { Cost ( } \% \text { of property } \\
\text { value) }\end{array}$ & 11 & 18 & 21 & 27 & 17 & 6 & 11 & 22 & 11 & 11 & 5 & 7 & 2 & 2 \\
\hline $\begin{array}{l}\text { Rank } \\
\text { Getting Credit }\end{array}$ & 166 & 134 & 123 & 168 & 153 & 56 & 148 & 173 & 123 & 121 & 71 & 157 & 8 & 74 \\
\hline Legal Rights Index & 3 & 3 & 3 & 3 & 3 & 2 & 3 & 7 & 4 & 5 & 3 & 5 & 3 & 4 \\
\hline $\begin{array}{l}\text { Credit Information } \\
\text { Index }\end{array}$ & 4 & 2 & 1 & 2 & 1 & 2 & 2 & 0 & 1 & 3 & 6 & 4 & 2 & 0 \\
\hline $\begin{array}{l}\text { Public registry } \\
\text { coverage ( } \% \text { adults) }\end{array}$ & 2.3 & 1 & 0.2 & 2.4 & 2.8 & 1.9 & 2.4 & 0 & 2 & 21 & 0 & 0 & 1 & 0 \\
\hline $\begin{array}{l}\text { Private bureau } \\
\text { coverage (\% adults) }\end{array}$ & 0 & 0 & 0 & 0 & 0 & 0 & 0 & 0 & 5 & 0 & 61 & 34 & 0 & 0 \\
\hline $\begin{array}{l}\text { Rank } \\
\text { Protecting Investors }\end{array}$ & 84 & 115 & 135 & 115 & 135 & 135 & 115 & 84 & 114 & 68 & 48 & 48 & 115 & 135 \\
\hline Disclosure Index & 5 & 6 & 6 & 6 & 6 & 6 & 6 & 5 & 5 & 9 & 8 & 4 & 4 & 3 \\
\hline Director Liability Index & 6 & 1 & 1 & 1 & 1 & 1 & 1 & 7 & 3 & 5 & 5 & 9 & 7 & 3 \\
\hline $\begin{array}{l}\text { Shareholder Suits } \\
\text { Index }\end{array}$ & 6 & 6 & 5 & 3 & 3 & 4 & 3 & 5 & 5 & 3 & 5 & 7 & 2 & 2 \\
\hline $\begin{array}{l}\text { Investor Protection } \\
\text { Index }\end{array}$ & 5.7 & 4.3 & 4 & 3.3 & 3.3 & 3.7 & 3.3 & 5.7 & 4 & 6 & 6 & 7 & 4 & 2.7 \\
\hline $\begin{array}{l}\text { Rank } \\
\text { Paying Taxes }\end{array}$ & 51 & 107 & 122 & 147 & 147 & 141 & 147 & 51 & 111 & 51 & 33 & 15 & 107 & 165 \\
\hline Payments (number) & 31 & 41 & 54 & 89 & 66 & 45 & 28 & 35 & 39 & 51 & 27 & 40 & 14 & 70 \\
\hline Time (hours) & 272 & 1400 & 122 & 606 & 270 & 212 & 272 & 1120 & 321 & 266 & 552 & 114 & 12 & 864 \\
\hline Total tax rate (\% profit) & 53.2 & 51.9 & 63.7 & 65.4 & 45.4 & 62.2 & 44.2 & 29.9 & 68 & 37 & 51.2 & 33 & 14 & 53.3 \\
\hline Rank & 120 & 166 & 124 & 176 & 140 & 136 & 93 & 107 & 106 & 110 & 135 & 45 & 4 & 174 \\
\hline $\begin{array}{l}\text { Trading Across } \\
\text { Borders }\end{array}$ & & & & & & & & & & & & & & \\
\hline Time for export (days) & 64 & 27 & 78 & 50 & 23 & 29 & 19 & 26 & 36 & 21 & 17 & 14 & 13 & 45 \\
\hline $\begin{array}{l}\text { Cost to export (US\$ } \\
\text { per container) }\end{array}$ & 1850 & 907 & 4867 & 2201 & 1653 & 1403 & 1510 & 1026 & 1660 & 667 & 1302 & 693 & 462 & 2400 \\
\hline Time for import (days) & 58 & 33 & 102 & 62 & 43 & 46 & 35 & 46 & 44 & 27 & 23 & 26 & 13 & 65 \\
\hline $\begin{array}{l}\text { Cost to import (US\$ } \\
\text { per container) }\end{array}$ & 2325 & 1529 & 5520 & 2201 & 2457 & 1403 & 1600 & 1047 & 1986 & 623 & 2411 & 1100 & 462 & 2400 \\
\hline $\begin{array}{l}\text { Rank } \\
\text { Enforcing Contracts }\end{array}$ & 164 & 132 & 157 & 171 & 147 & 133 & 106 & 138 & 131 & 41 & 76 & 49 & 24 & 156 \\
\hline Procedures (number) & 46 & 43 & 41 & 44 & 33 & 40 & 38 & 39 & 39 & 39 & 38 & 42 & 50 & 29 \\
\hline Time (days) & 1011 & 800 & 743 & 560 & 770 & 553 & 1070 & 457 & 643 & 570 & 415 & 1340 & 607 & 510 \\
\hline Cost (\% of debt) & 44.4 & 46.6 & 77.4 & 53.2 & 41.7 & 18.5 & 34.3 & 32 & 49 & 123 & 32 & 34 & 26 & 43.7 \\
\hline & 176 & 172 & 167 & 156 & 122 & 72 & 145 & 93 & 115 & 141 & 83 & 168 & 144 & 70 \\
\hline $\begin{array}{l}\text { Closing a Business } \\
\text { Time (years) }\end{array}$ & 6.2 & 3.2 & NP & 3 & 2.2 & NP & 5 & 2 & 3 & 6 & 2 & NP & 5 & 4 \\
\hline Cost (\% of estate) & 22 & 15 & NP & 24 & 18 & NP & 15 & 22 & 20 & 18 & 18 & NP & 30 & 38 \\
\hline $\begin{array}{l}\text { Recovery rate (cents } \\
\text { on the dollar) }\end{array}$ & 10.8 & 25.5 & 0 & 20.4 & 33 & 0 & 15.2 & 27.5 & 17 & 13 & 63.9 & 0 & 10 & 6.6 \\
\hline Rank & 138 & 92 & 178 & 110 & 71 & 178 & 130 & 89 & 121 & 136 & 23 & 178 & 139 & 146 \\
\hline
\end{tabular}

${ }^{1} \mathrm{AGO}=$ Angola; $\mathrm{CMR}=$ Cameroon; $\mathrm{TCD}=\mathrm{Chad} ; \mathrm{COG}=$ Congo (Rep. of); $\mathrm{CIV}=$ Côte d'Ivoire; $\mathrm{GNQ}=$ Equatorial Guinea; $\mathrm{GAB}=\mathrm{Gabon}$;

NGA=Nigeria; IDN=Indonesia; MEX=Mexico; TTO=Trinidad and Tobago; ARE=United Arab Emirates; VEN=Venezuela; $N P=N o$ Practice Source: World Bank's Doing Business database (http://www.doingbusiness.org/) . 


\section{APPENDiX B: DATA SOURCES AND SENSIITIVITY RESUlTS}

Table B1. Data sources

\begin{tabular}{ll}
\hline Variable & Source \\
\hline & \\
Trade & UN-COMTRADE database \\
Real GDP (constant 2000 US\$) & World Bank's World Development Indicators, 2007 \\
Real GDP per capita(constant 2000 US\$) & World Bank's World Development Indicators, 2007 \\
Distance 1/ & CIA's World Factbook \\
Common language & CIA's World Factbook \\
Common border & CIA's World Factbook \\
Landlocked; Island & CIA's World Factbook \\
Land area & CIA's World Factbook \\
Colonial ties & CIA's World Factbook \\
Currency unions and trade agreements & Tsangarides et al. (2007) \\
Adult literacy rate & World Bank's World Development Indicators, 2007 \\
Human development index & Human Development Report 2007/08 \\
Transport infrastructure (\% of paved roads) & World Bank's World Development Indicators, 2007 \\
World governance indicators & World Bank \\
Doing business indicators & World Bank \\
Corruption, bureaucratic quality, government stability & The Political Risk Services Group \\
\hline \hline 1 l Distance between two countries calculated using the great circle method.
\end{tabular}

1/ Distance between two countries calculated using the great circle method.

Table B2. Summary statistics of selected variables

\begin{tabular}{lcc}
\hline Variable & Mean & Std. Deviation \\
\hline Log of real non-oil exports & -5.95 & 3.51 \\
Log real GDP (origin) & 23.28 & 2.33 \\
Log real GDP (destination) & 23.28 & 2.33 \\
FTA & 0.02 & 0.16 \\
Log distance & 8.25 & 0.78 \\
Common language & 0.17 & 0.37 \\
Common land border & 0.02 & 0.13 \\
Number landlocked in the pair & 0.33 & 0.53 \\
Number islands in the pair & 0.42 & 0.58 \\
Current colony & 0.00 & 0.04 \\
Ever colony & 0.01 & 0.10 \\
Log oil export share in total exports & -3.78 & 6.43 \\
Corruption & 0.51 & 0.23 \\
Bureaucratic quality & 0.54 & 0.29 \\
Government stability & 0.55 & 0.22 \\
\hline \hline
\end{tabular}

Source: Author's calculations based on data obtained from sources listed in Table B1. 
Table B3: Trade potential: Gravity model estimates

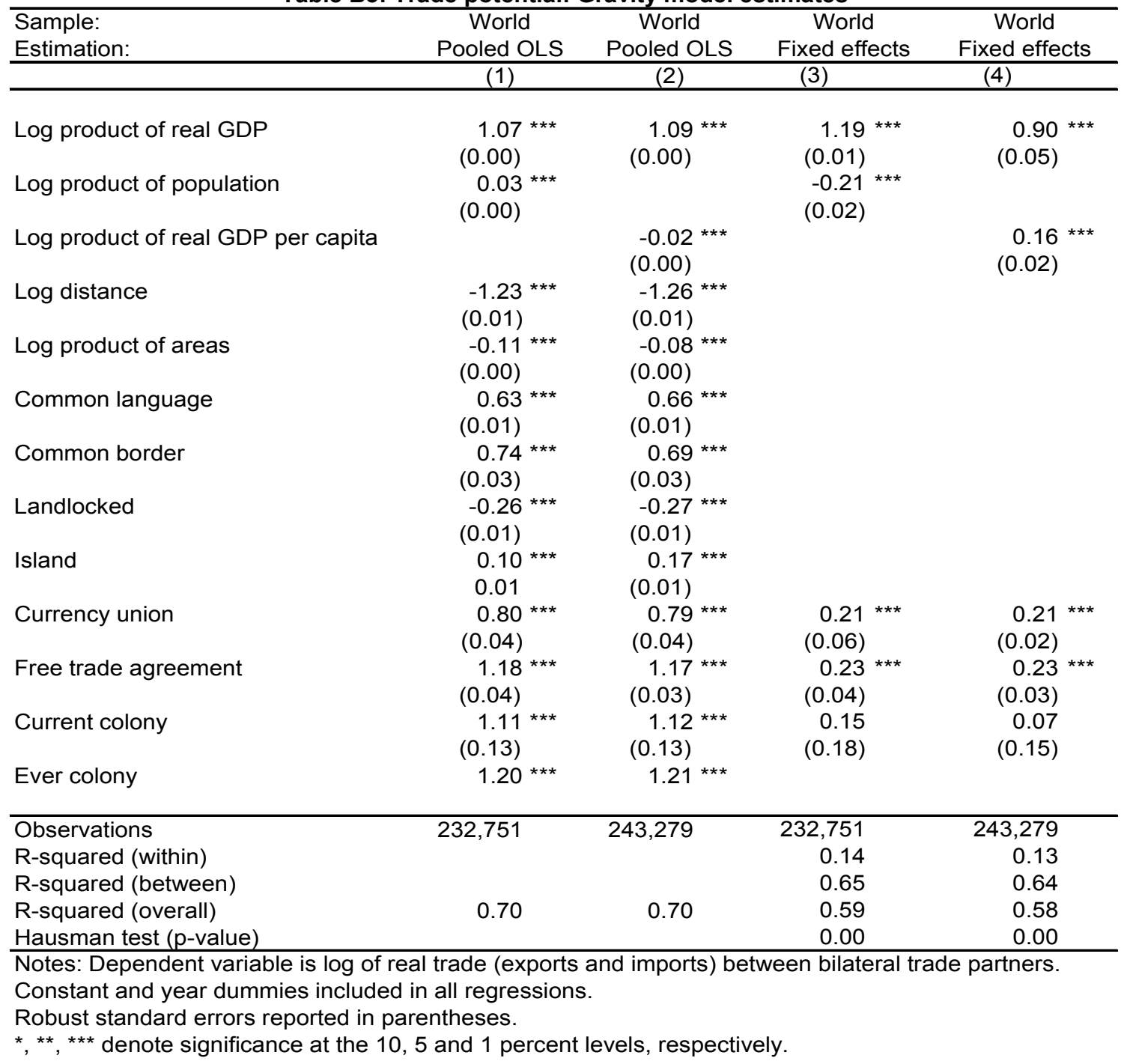

Table B4: Undertrading in the OPAC and selected regions, 1970-2005

\begin{tabular}{lrrrrr}
\hline & $\mathbf{1 9 7 0 - 2 0 0 6}$ & $\mathbf{1 9 7 0 - 7 9}$ & $\mathbf{1 9 8 0 - 8 9}$ & $\mathbf{1 9 9 0 - 9 9}$ & $\mathbf{2 0 0 0 - 0 5}$ \\
\hline OPAC & 0.02 & 0.42 & 0.27 & -0.16 & -0.24 \\
SSA & 0.01 & 0.50 & 0.25 & -0.14 & -0.29 \\
Indonesia & 0.17 & -0.47 & -0.06 & 0.40 & 0.55 \\
Mexico & -1.64 & -1.74 & -1.94 & -1.50 & -1.29 \\
Trinidad and 7 & -0.27 & 0.59 & 0.03 & -0.76 & -0.66 \\
UAE & 0.22 & 0.22 & 0.06 & 0.17 & 0.46 \\
Venezuela & -0.96 & -0.44 & -0.58 & -1.37 & -1.35 \\
\hline
\end{tabular}

Notes: Estimates calculated using the average difference between actual and predicted (log of) real trade obtained from model (4) in Table B3.

Source: Author's estimates. 
Table B5: PPML estimates of the Gravity Model

\begin{tabular}{|c|c|c|c|c|c|c|}
\hline Sample: & World & World & World & World & Low institutions & High institutions \\
\hline & $(1)$ & $(2)$ & (3) & (4) & (5) & (6) \\
\hline \multirow[t]{2}{*}{ Log real GDP (origin) } & $1.08^{* * *}$ & $1.05^{* * *}$ & $1.09 * * *$ & $1.09 * * *$ & $0.53^{* * *}$ & $1.04^{* * *}$ \\
\hline & $(0.05)$ & $(0.05)$ & $(0.05)$ & $(0.05)$ & $(0.16)$ & $(0.03)$ \\
\hline \multirow[t]{2}{*}{ Log real GDP (destination) } & $0.98^{* * *}$ & $0.98^{* * *}$ & $0.99 * * *$ & $0.98^{* * *}$ & $0.98^{* * *}$ & $0.91^{* * *}$ \\
\hline & $(0.04)$ & $(0.04)$ & $(0.04)$ & $(0.04)$ & $(0.15)$ & $(0.03)$ \\
\hline \multirow[t]{2}{*}{ Free trade agreement } & $0.41^{* * *}$ & $0.39^{* * *}$ & $0.40 * * *$ & $0.42^{* * *}$ & $0.97 * * *$ & $0.41^{* * *}$ \\
\hline & $(0.03)$ & $(0.03)$ & $(0.03)$ & $(0.03)$ & $(0.13)$ & $(0.02)$ \\
\hline \multirow[t]{2}{*}{ Log oil export share (Oil) } & $-0.01 *$ & $-0.01 *$ & $-0.01 *$ & $-0.01 * *$ & $-0.03 *$ & $0.01 * * *$ \\
\hline & $(0.00)$ & $(0.01)$ & $(0.00)$ & $(0.00)$ & $(0.02)$ & $(0.00)$ \\
\hline \multirow[t]{2}{*}{ Corruption (Corr) } & 0.02 ** & & & & & \\
\hline & $(0.06)$ & & & & & \\
\hline \multirow[t]{2}{*}{ Corr * Oil } & $0.01 * *$ & & & & & \\
\hline & $(0.00)$ & & & & & \\
\hline \multirow[t]{2}{*}{ Bureaucratic quality (Burq) } & & $0.45^{* * *}$ & & & & \\
\hline & & $(0.07)$ & & & & \\
\hline \multirow[t]{2}{*}{ Burq * Oil } & & 0.02 ** & & & & \\
\hline & & $(0.01)$ & & & & \\
\hline \multirow[t]{2}{*}{ Government stability (Stab) } & & & 0.06 * & & & \\
\hline & & & $(0.04)$ & & & \\
\hline \multirow[t]{2}{*}{ Stab * Oil } & & & 0.00 & & & \\
\hline & & & $(0.00)$ & & & \\
\hline \multirow[t]{2}{*}{ Institutional quality (Inst) } & & & & 0.02 * & & \\
\hline & & & & $(0.01)$ & & \\
\hline \multirow[t]{2}{*}{ Inst * Oil } & & & & $0.01^{\star * *}$ & & \\
\hline & & & & $(0.00)$ & & \\
\hline \multirow[t]{2}{*}{ Log of infrastructure } & $0.30^{* * *}$ & $0.30 * * *$ & $0.30^{* \star *}$ & $0.30^{* \star *}$ & 0.13 * & $0.33^{* \star *}$ \\
\hline & $(0.02)$ & $(0.02)$ & $(0.06)$ & $(0.02)$ & $(0.07)$ & $(0.02)$ \\
\hline Observations & 241,576 & 241,263 & 241,499 & 241,221 & 95,791 & 268,632 \\
\hline Wald chi-square ( $p$-value) & 0.00 & 0.00 & 0.00 & 0.00 & 0.00 & 0.00 \\
\hline Hausman test ( $p$-value) & 0.00 & 0.00 & 0.00 & 0.00 & 0.00 & 0.00 \\
\hline
\end{tabular}

